\title{
Long Term Resource Conservation Technologies Sustained Yield, Microbial Activities and Soil Physico-chemical Properties in Rice-green Gram Cropping System
}

\author{
Pradeep Kumar Dash \\ ICAR National Rice Research Institute \\ Pratap Bhattacharyya \\ ICAR National Rice Research Institute \\ Mohammad Shahid \\ ICAR National Rice Research Institute \\ Upendra Kumar \\ ICAR National Rice Research Institute \\ Soumya Ranjan Padhy \\ ICAR National Rice Research Institute \\ Chinmaya Kumar Swain \\ ICAR National Rice Research Institute \\ Anshuman Senapati \\ ICAR National Rice Research Institute \\ Priyanka Bihari \\ ICAR National Rice Research Institute \\ Amaresh Kumar Nayak ( $\sim$ aknayak20@yahoo.com ) \\ ICAR National Rice Research Institute
}

\section{Research Article}

Keywords: agroecology, resource conservation technology, rice-green gram, microbial biomass, microbial activity, relative yield

Posted Date: November 18th, 2021

DOI: https://doi.org/10.21203/rs.3.rs-1063991/v1

License: () (1) This work is licensed under a Creative Commons Attribution 4.0 International License. Read Full License 


\section{Abstract}

Purpose

Microbial communities in rhizospheric soil play a significant role in sustaining the soil quality and also recognized as key ecological indicators to assess the soil health.

Methods

We studied the long-term effects of resource conservation technologies on functional microbial diversity and their interactions with soil biochemical properties and enzymatic activities in tropical rice-green gram cropping system. The experiment included conventional practice (CC), brown manuring (BM), green manuring (GM), wet direct drum sowing (WDS), zero tillage (ZT), green manuring-customized leaf colour chart based-N application (GM-CLCC N) and biochar (BC) treatments.

Results

The result revealed that microbial biomass nitrogen $(\mathrm{N})$, carbon $(\mathrm{C})$ and phosphorus $(\mathrm{P})$ in GM practice increased by $23.3,37.7$ and $35.1 \%$, respectively over CC. The Shannon index and Mclntosh index were higher by $86.9 \%$ and $29.2 \%$ in GM as compared to conventional practice and significantly correlated with microbial biomass (C \& P) and soil microbial populations whereas, Shannon index was positively correlated with the microbial biomass (C, N \& P) and soil enzyme activities. Principal component analysis showed a significant separate cluster among the treatments amended with and without biomass addition.

\section{Conclusions}

Moreover, dominance of carbon utilizing microbes in biomass amended treatments indicated that these could supply good amount of labile carbon sources on real time basis for microbial activity. Which may protect the stable carbon fraction in soil, hence could support higher build-up of carbon in long run and could offer sustainable yield under rice-green gram soil.

\section{Introduction}

The relationships of soil microorganisms and ecosystems are highly complex. The soil biota are essential for several ecosystem functions including nutrientcycling, biomass decomposition, soil organic matter (SOM) restoration and maintenance of plant health ( Zhang et al., 2012; Dossou-Yovo et al., 2016; Dash et al., 2017; Kumar et al., 2017). However, microbial population structure and their function in soils were influenced by several environmental factors (Kibblewhite et al., 2008) and the addition of different soil amendments (Benbi et al., 2016) , which could alter the soil characteristics (Li et al., 2011; Shahid et al., 2017). Soil microbes also interact directly with soil environment as well as their extracellular enzyme activities that play a vital role in decomposition process for nutrients (carbon, nitrogen, phosphorous and sulphur) availability (Hartmann et al., 2006). These indicators suit for assessing soil microbial activities which improve the soil fertility resulting crop growth productivity (Acosta-martínez et al., 2011; Min et al., 2016).

Different resource conservation technologies (RCTs) are now being popular due to concerns about soil fertility deterioration as a consequences of exhaustive tillage practices (Ladha et al., 2003). Resource conservation practices like zero tillage; biomass retention etc. have minimized soil erosion, enhanced nutrient conservation and fetched low economic input (Lal, 2004). The researchers are also assessing the economic turn outs different nutrient management practices and tillage operations under RCTs to understand the behaviour of soil biochemical properties. However, such nutrient management in resource conservation practices affect soil microbial diversities both structural and functional and thereby influence the soil biochemical properties (Cookson et al., 2007).

Applications of chemicals and fertilizers affect the soil biota and their functions (Anderson, 2003; Weber et al., 2008; Su et al., 2015; Kumar et al., 2017; Shahid et al., 2017). The direct effects include shift in soil pH and heavy metals accumulation which negatively impacted the soil microbiota (Zhang et al., 2012; Turner et al., 2013; Chen et al., 2016). The indirect effects through stimulation of the soil microbiota activity and of crop growth due to higher residues inputs and rhizo-depositions to soil (Su et al., 2015; Tang et al., 2016). Studies conducted under different climatic regimes have shown that the extracellular enzymatic activities respond towards minimum modifications in the environmental conditions and organic and mineral fertilization management practices, tillage operations and applications of pesticides and herbicides (Tejada et al., 2008; E. Liu et al., 2014; Jacobsen and Hjelms $\varnothing$, 2014; Wezel et al., 2014). The $\beta$ glucosidase is an important soil quality indicator used to evaluate the impacts of different cultural practices on physicochemical properties and organic matter stabilization in soil (García-Gil et al., 2000; Badiane et al., 2001). Other enzymes like dehydrogenase, fluorescein di-acetate, urease, cellulase etc. are also good indicators of soil fertility (Wanjiru et al., 2015; Tautges et al., 2016).

Long-term resource conservation practices are valuable for residue management and evaluation the residual effects of tillage on soil microbial diversities (both structural and functional) (Lienhard et al., 2013; Pandey et al., 2014). Long-term application of soil amendments (both inorganic and organic) affect the soil microbial communities in different agro-ecosystems (Zhong and Cai, 2007; Baudoin et al., 2009; Wanjiru et al., 2015). Profiling of different carbon source utilization by groups of soil microbes under different fertilization treatments can be significantly generated by using Biolog eco- plates (Kumar et al., 2017). Some researchers reported that measurement of soil microbial diversity through Biolog alone is not a valid method (Zhou et al., 2008; Tan et al., 2013), however, it gives the indication towards functional microbial diversity.

Rice-green gram system is a widely practiced cropping system in India (Raja et al., 2015; Shahid et al., 2017) however, information on long-term effect of resource conservation practices involving different sources of organic matter and methods of incorporation into the soil in rice-green gram cropping system are lacking. Further, the effect of rice-green gram system on soil fertility due to temporal shifts of functional microbial diversity in rhizospheric soil is also limited. Hence, the objectives of the study were formulated to find out the effects of resource conservation technologies on (i) soil chemical and biological 
properties, and changes of functional diversity of soil microbial communities and (ii) to study the relationship among microbial biomass (C, N \& P), and soil enzymes in rice-green gram system.

\section{Materials And Methods}

\section{Experimental setup}

The study area of the long-term resource conservation technology was situated at ICAR-National Rice Research Institute (NRRI), Cuttack (20 $44^{\prime} \mathrm{N}, 85^{\circ} 94^{\prime} \mathrm{E}$ ) and continuously practiced for five years. The climate of this area has sub-humid tropical. The annual mean precipitation is around $1500 \mathrm{~mm}$; occurred during the month of June-September and the minimum and maximum mean annual temperatures were $22.5 \otimes \mathrm{C}$ and $39.2 \varangle \mathrm{C}$, respectively. The soils of the experimental field were classified as 'Aeric Endoaquept' having a sandy clay loam texture ( $17 \%$ silt, $30 \%$ clay and $56 \%$ sand). Some of the initial characteristics of the surface soil $\left(0-15 \mathrm{~cm}\right.$ ) were as follows: $\mathrm{pH}$ was 6.6 (using soil: water suspension, $1: 2.5$ ); electrical conductivity (EC) $0.49 \mathrm{dS} \mathrm{m}^{-1}$; bulk density $1.40 \mathrm{Mg}$

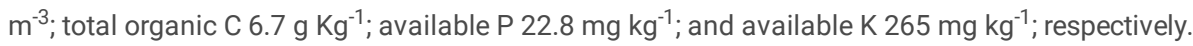

The study was conducted during dry season of 2016-17 in the long-term experiment of resource conservation technologies which has been initiated in 2012. There were total seven (7) treatments and arranged in a completely randomized block design (CRBD). The treatments were conventional practice (CC), brown manuring (BM), green manuring (GM), wet direct drum sowing (WDS), zero tillage (ZT), green manuring + CLCC-N (GM-CLCC N) and biochar (BC) application, which were replicated thrice (experimental details are given in Table 1). Rice-rice system was followed for initial two years (2012-2014) and then rice-green gram system for three years (2014-17). In our experiment, rice and green gram; varieties were Pooja and Samrat, respectively. The line $\times$ plant spacing was $20 \times 15 \mathrm{~cm}$ in rice and $30 \times 10 \mathrm{~cm}$ in green gram. The recommended dose of fertilizer (RDF) for $\mathrm{N}: \mathrm{P}_{2} \mathrm{O}_{5}: \mathrm{K}_{2} \mathrm{O}$ were at the rate of $80: 40: 40 \mathrm{~kg}$ $\mathrm{ha}^{-1}$ for

Table 1 Treatment details of the resource conservation experiment

\begin{tabular}{|c|c|c|}
\hline \multirow[t]{2}{*}{ Treatments } & \multicolumn{2}{|l|}{ Practice Followed } \\
\hline & Wet Season & $\begin{array}{l}\text { Dry Season (Green } \\
\text { gram) }\end{array}$ \\
\hline $\begin{array}{l}\text { Conventional } \\
\text { Control } \\
\text { (CC) }\end{array}$ & Manual wet direct sowing + Manual weeding + 100\% RDF + Manual harvesting & $\begin{array}{l}\text { Conventional tillage + } \\
\text { Line sowing + Manual } \\
\text { weeding }\end{array}$ \\
\hline $\begin{array}{l}\text { Brown } \\
\text { Manuring } \\
\text { (BM) }\end{array}$ & $\begin{array}{l}\text { Dry direct sowing + Inter cropping Sesbania aculeata and knocking down of by 2,4-D at } 25 \text { days after sowing + } \\
75 \% \mathrm{~N}+\text { mechanical weeding + mechanical harvesting }\end{array}$ & $\begin{array}{l}\text { Conventional tillage }+ \\
\text { Line sowing + Manual } \\
\text { weeding }\end{array}$ \\
\hline $\begin{array}{l}\text { Green } \\
\text { Manuring } \\
(\mathrm{GM})\end{array}$ & $\begin{array}{l}\text { Dry direct sowing + Inter cropping Sesbania aculeata and incorporation through cono-weeder at } 25 \text { days after } \\
\text { sowing }+75 \% \mathrm{~N}+\text { mechanical weeding + mechanical harvesting }\end{array}$ & $\begin{array}{l}\text { Conventional tillage }+ \\
\text { Line sowing + Manual } \\
\text { weeding }\end{array}$ \\
\hline $\begin{array}{l}\text { Wet Drum } \\
\text { Seeding } \\
\text { (WDS) }\end{array}$ & Wet direct sowing by drum seeder + mechanical weeding $+100 \%$ RDF + Mechanical harvesting & $\begin{array}{l}\text { Conventional tillage + } \\
\text { Line sowing + Manual } \\
\text { weeding }\end{array}$ \\
\hline $\begin{array}{l}\text { Zero Tillage } \\
(\mathrm{ZT})\end{array}$ & $\begin{array}{l}\text { Zero tilled dry direct sowing + Residue retention }(20 \mathrm{~cm} \text { above the ground })+75 \% \mathrm{~N}+\text { Chemical weeding }+ \\
\text { Manual harvesting }\end{array}$ & $\begin{array}{l}\text { Zero tillage + Line } \\
\text { sowing+ chemical } \\
\text { weeding }\end{array}$ \\
\hline $\begin{array}{l}\text { Green } \\
\text { Manuring- } \\
\text { CLCC-N }\end{array}$ & $\begin{array}{l}\text { Paired row dry direct sowing rice with seed drill with one row Sesbania aculeata intercropping and incorporation } \\
\text { at } 25 \text { days through cono-weeder) }+75 \% \mathrm{~N}+\text { customized leaf colour chart based } \mathrm{N} \text { management + mechanical } \\
\text { weeding + Mechanical harvesting }\end{array}$ & $\begin{array}{l}\text { Conventional tillage }+ \\
\text { Line sowing + Manual } \\
\text { weeding }\end{array}$ \\
\hline
\end{tabular}

(GM-CLCC-N)

Biochar Wet direct sowing by drum seeder + biochar (5t/ ha) $+100 \%$ RDF + mechanical weeding + Mechanical harvesting

Conventional tillage + Line sowing + Manual weeding

wet-season rice and 20: 40: $20 \mathrm{~kg} \mathrm{ha}^{-1}$ for dry-season green gram, respectively. The nitrogen ( $\mathrm{N}$ ) was given as neem coated urea in three splits, i.e. half (50\%) at basal and rest (25\%) each at two top dressings to rice. However, the entire $\mathrm{N}$ fertilizer was applied in green gram as basal dose. The single superphosphate (SSP) and muriate of potash $(\mathrm{KCl})$ was applied as phosphorus and potassium fertilizer, respectively only as basal dose. Under green and brown manuring treatments, $25 \%$ less of nitrogen fertilizer was given in the wet season of rice. At the rate of $25 \mathrm{~kg} \mathrm{ha}^{-1}$, Sesbania aculeata was sown for both the treatments. The 25 days old Sesbania aculeata were knocked down in green manuring treatments by using cono-weeder; however, in brown manuring treatment, Sesbania was killed with the help of 2, 4-D. The real time N-management was done with the help of customized leaf colour chart (CLCC). In biochar treatment at the beginning of the experiment, rice husk biochar was applied at $5 \mathrm{t} \mathrm{ha}^{-1}$. The biochar was prepared by the process of pyrolysis at high temperature (300凶C) for 6 h. During wet season, check-basin irrigation method was followed and irrigation was given at every 3 to 5 days of interval to maintain water level up to $5 \pm 2$ $\mathrm{cm}$, whereas, irrigation was applied only at flowering stage of green gram in the dry-season. Apart from this, for weeds, insects and diseases control the standard recommended protocol were followed. 
The soil samples were collected during dry season of 2016-17 after harvesting of the crop (green gram) at four places randomly from each treatment at 0-15 $\mathrm{cm}$ depth by using sample probe. The soil collected was mixed thoroughly and homogenize properly to prepare the composite soil for all the treatments separately. One set of fresh soil samples which was used for biochemical as well as microbial analysis were kept at $4{ }^{\circ} \mathrm{C}$ in refrigerator, and rest portion of the soil soil was air dried in shade for 7 days and then processed, through $2 \mathrm{~mm}$ sieve and stored in seal container for further analysis.

\section{Soil physico-chemical properties}

Soil pH (soil: water::1: 2.5) and electrical conductivity $(\mathrm{EC})$ were analysed in soil with water suspension and soil saturation extract, respectively by using standard methods. Total organic carbon was estimated by potassium dichromate $\left(\mathrm{K}_{2} \mathrm{Cr}_{2} \mathrm{O}_{7}\right)$ along with sulphuric acid $\left(\mathrm{H}_{2} \mathrm{SO}_{4}\right)$ and $85 \%$ o-phosphoric acid $\left(\mathrm{H}_{3} \mathrm{PO}_{4}\right)$ digestion mixture with a ratio of $3: 2$ by wet digestion method in a digestion block set for $2 \mathrm{~h}$ at $120{ }^{\circ} \mathrm{C}$ temperature (Snyder and Trofymow, 1984). Available nitrogen (AN) (Hati et al., 2008), available phosphorus (AP) (Bray R.H and Kurtz L.T, 1945) and available potassium (AK) (Hati et al., 2007) were analysed using standard methods.

\section{Biological properties of soil}

Soil microbial biomass carbon (MBC) was estimated by using chloroform fumigation-extraction method in which, one set of soil sample was fumigated in vacuum desiccator while other was kept un-fumigated (Witt et al., 2000). Microbial biomass nitrogen (MBN) was analysed following the method of Ross, 1990. Dehydrogenase (DHA) activity was estimated by the formation of 2,3,5-triphenylformazan (TPF) as a result of the reduction of 2,3, 5-

triphenyltetrazolium chloride (TTC) (Casida et al., 1964). Fluorescein di-acetate (FDA) hydrolysis and $\beta$-glucosidase activities were measured by following the method of Adam and Duncan, 2001 and Eivazi and Tabatabai, 1988, respectively. Urease activity was estimated by following the method of P. Bhattacharyya et al., 2012. The $\mathrm{C}$ and $\mathrm{N}$ mineralization were determined by incubating the soil samples for one month. After, incubation the $\mathrm{C}$ mineralization ( $\left.\mathrm{C}_{\mathrm{min}}\right)$ was estimated followed by alkali traps method (Mohanty et al., 2013). However, for $\mathrm{N}$ mineralization $\left(\mathrm{N}_{\text {min }}\right)$, the mineral $\mathrm{N}\left(\right.$ both $\mathrm{NH}_{4}-\mathrm{N}$ and $\left.\mathrm{NO}_{3}-\mathrm{N}\right)$ was determined by extraction with $2 \mathrm{M} \mathrm{KCl}$ of the incubated soil samples (Abera et al., 2012). Finally, the net $\mathrm{N}$ and $\mathrm{C}$ mineralization were estimated and the cumulative $\mathrm{N}_{\text {min }}$ and $\mathrm{C}_{\text {min }}$ were determined. The aerobic heterotrophic bacterial, fungal and actinomycetes populations were enumerated by adopting the procedure of (Kumar et al., 2017).

\section{Soil microbial community and functional diversity}

Soil microbial activity and diversity in the rhizospheric soil was investigated by using Biolog plates (Biolog Inc., CA, USA). Biolog plate consists of 96 wells consisted of one control along with 31 different carbon sources with three replications each. Equivalent to $10 \mathrm{~g}$ dry weight of fresh soil sample was taken in a $250 \mathrm{ml}$ conical flask, then $100 \mathrm{ml}$ of distilled water was added and put it in a shaker for 30 minutes at $250 \mathrm{rpm}$. Then the soil suspension was diluted to $10^{-3}$ and $150 \mu \mathrm{L}$ of this final suspension was inoculated in a Biolog plate and incubated at $25^{\circ} \mathrm{C}$. After incubation of $0,24,48,72,96$ and $120 \mathrm{~h}$, carbon utilization by the microbial community by taking the absorbance of each well at $590 \mathrm{~nm}$. The data were recorded using Microlog 4.01 and to assess total microbial activity the average well color development (AWCD) of the all carbon sources was measured as:

$\mathrm{AWCD}=[\Sigma(\mathrm{C}-\mathrm{R})] / 31]$

Where, $\mathrm{C}$ and $\mathrm{R}$ refer to the optical density (OD) value of the reaction wells and control well, respectively (Li et al., 2012). The AWCD reflects the overall utilization of different carbon sources by the soil microbial community (Choi and Dobbs, 1999).

\section{Functional diversity analysis by utilizing different carbon sources}

The McIntosh $(\mathrm{U})$ and Shannon-Weaver $(\mathrm{H})$ indices were estimated from absorbance of the Biolog eco-plates that express the functional microbial diversity of soil. The Shannon-Weaver index is sensitive to the species richness of the microbial diversity and it is calculated by the formula:

$H=-\sum \mathrm{pi} \ln \mathrm{pi}$

"pi refers to the ratio of relative absorbance $(C-R)$ of $\mathrm{i}^{\text {th }}$ well to the sum of relative OD values of all the wells.

Similarly, Mclntosh index is the measurements of species evenness of the microbial community and it was quantified by using following formula.

$\mathrm{U}=\sqrt{ } \sum(\mathrm{ni})^{2}$

ni, refers to the relative OD for each of the carbon source wells by subtracting the OD value of control well (Guanghua et al., 2008; An et al., 2014).

\section{Relative yield}

Relative yield was calculated from mean seasonal rice and rice equivalent (green gram) yields, which was expressed as $\mathrm{Mg} \mathrm{ha}^{-1}$.

Rice equivalent yield (REY):

The equivalent yield was estimated in kharif crop (rice) by using the equation.

$R E Y=\frac{\text { Yield of green gram } \times M S P \text { of green gram }}{M S P \text { of rice }}$ 
Where, MSP= minimum support price.

\section{Statistical analysis}

Analysis of variance (ANOVA) of individual character and means were compared with DMRT at significant level $(p \leq 0.05)$ was done by online software version OP STAT. The microbial biomass and activities were analysed by using the coordinate of the points obtained by the principal component analysis (PCA) method in two ways ANOVA. The OD values taken from the Biolog eco-plates of 31 different carbon sources utilization were used to perform the analysis. Multi-element vectors describing the metabolism of microbial communities were obtained from the PCA analysis. The six major carbon classes were made by using 31 kind of different $C$ sources, then the AWCD values of six major classes of carbon sources were normalized in Microsoft excels and analysed by ANOVA and PCA using the SAS (9.2) software.

\section{Results}

\section{Relative yield}

Relative yield of the experiment was found in the range of $4.19-4.95 \mathrm{Mg} \mathrm{ha}^{-1}$ and it was significantly more under green manuring (GM; $\left.4.95 \mathrm{Mg}^{-1}\right)$ and lowest under biochar (BC) treatment (4.19 $\mathrm{Mg} \mathrm{ha}^{-1}$ ) (Fig. 1).

\section{Soil physico-chemical and biological activities}

Soil physico-chemical as well as biological properties were influenced by different resource conservation practices. The $\mathrm{pH}$ of the soils in different treatments ranged from 6.6 to 6.8 and was found to be non-significant. Electrical conductance (EC) was varied from 0.46 to $0.48 \mathrm{dS} \mathrm{m}{ }^{-1}$ among the treatments. Total organic carbon was ranged from 6.8 to $8.7 \mathrm{~g} \mathrm{Kg}^{-1}$ and was significantly higher under zero tillage practice compared to others. Highest available $\mathrm{N}$ content was also recorded under green manuring $\left(326.1 \mathrm{~kg} \mathrm{ha}^{1}\right)$, followed by biochar and brown manuring treatments. Similarly, highest available phosphorous $(\mathrm{P})$ and potassium $(\mathrm{K})$ contents were recorded under green manuring, followed by zero tillage and brown manuring treatments.

Microbial biomass carbon was in the range of $157.1 \mu^{-1}$ in control to $252.3 \mu \mathrm{g} \mathrm{g}^{-1}$ in green manuring treatments, whereas, MBN and MBP in the resultant soils were ranged from $24.5 \mu \mathrm{g} \mathrm{g}^{-1}$ to $31.9 \mu \mathrm{g} \mathrm{g}^{-1}$ and $12.8 \mu \mathrm{g} \mathrm{g}^{-1}$ to $19.7 \mu \mathrm{g} \mathrm{g}^{-1}$, respectively. The MBC, MBN and MBP were significantly more in green manuring amended plots compared to other treatments, however, significantly lower value of these parameters was found in control treatment. The activity of cellulase was varied in the range of 0.31 to $0.98 \mu$ g glucose $\mathrm{g}^{-1} \mathrm{~d}^{-1}$. The $\mathrm{C}_{\min }$ and $\mathrm{N}_{\min }$ were significantly more in plots treated with green manure than other treatments (Table 2). The content of dehydrogenase activity (DHA), fluorescein di-acetate activity (FDA), $\beta$-glucosidase activity, urease activity was found significantly higher in all resource conservation treatments as compared to control, while the highest activity was observed in green manuring treatment (Table 3). Similarly, cellulase, invertase and xylanase activities of soil were also significantly higher under all resource conservation treatments as compared to control, however, the higher activity was observed in zero tillage treatment (Table 3). Among different conservation treatments, the population of aerobic heterotrophic bacteria, fungi and actinomycetes were varied from 6.78 to $6.92 \log _{\text {CFU g}}{ }^{-1}, 4.55$ to $4.75 \log _{\text {CFU g }}{ }^{-1}, 4.47$ to 4.72 log CFU g$^{-1}$, respectively (Table 3). And the, green manuring treatment recorded the significantly $(\mathrm{p} \leq 0.05)$ higher population of these microbes.

Table 2 Soil physico-chemical properties under different resource conservation practices.

\begin{tabular}{|c|c|c|c|c|c|c|c|c|c|c|c|}
\hline Treatment & $\mathrm{pH}$ & EC & TOC & AN & AP & AK & MBC & MBN & MBP & $C_{\min }$ & $\mathrm{N}_{\min }$ \\
\hline $\mathrm{CC}$ & $6.6^{\mathrm{ns}}$ & $0.46^{\mathrm{a}}$ & $6.8^{f}$ & $238.3^{e}$ & $25.6^{\mathrm{b}}$ & $175.5^{b}$ & $157.1^{d}$ & $24.5^{d}$ & $12.8^{\mathrm{e}}$ & $891.8^{b}$ & $98.3 d$ \\
\hline BM & $6.7^{\mathrm{ns}}$ & $0.48^{a}$ & $7.5^{d}$ & $301.1^{\mathrm{b}}$ & $31.9^{\mathrm{a}}$ & $218.4^{\mathrm{a}}$ & $222.2^{b}$ & $29.5^{\mathrm{b}}$ & $17.3^{b}$ & $926.8^{a}$ & $117.6 \mathrm{~b}$ \\
\hline GM & $6.8^{\mathrm{ns}}$ & $0.49^{a}$ & $8.4^{b}$ & $326.1^{\mathrm{a}}$ & $34.9^{a}$ & $238.9^{a}$ & $252.3^{a}$ & $31.9^{a}$ & $19.7^{a}$ & $935.2^{\mathrm{a}}$ & $123.1 \mathrm{a}$ \\
\hline ZT & $6.8^{\mathrm{ns}}$ & $0.49^{a}$ & $8.7^{\mathrm{a}}$ & $275.1^{c}$ & $33.5^{\mathrm{a}}$ & $229.6^{a}$ & $190.2^{c}$ & $27.0^{c}$ & $15.6^{c}$ & $800.8^{d}$ & $76.0 f$ \\
\hline G M-CLCC-N & $6.7^{\mathrm{ns}}$ & $0.47^{a}$ & $8.1^{c}$ & $292.7^{b}$ & $33.0^{\mathrm{a}}$ & $225.9^{a}$ & $213.0^{b}$ & $31.1^{\mathrm{a}}$ & $16.9^{b}$ & $896.0^{b}$ & $105.7 \mathrm{c}$ \\
\hline $\mathrm{BC}$ & $6.7^{\mathrm{ns}}$ & $0.46^{\mathrm{a}}$ & $7.4^{\mathrm{d}}$ & $322.0^{a}$ & $26.2^{b}$ & $179.2^{b}$ & $241.6^{a}$ & $25.8^{\mathrm{cd}}$ & $14.1^{\mathrm{cd}}$ & $830.2^{c}$ & $93.5 \mathrm{~d}$ \\
\hline
\end{tabular}

† Different characters in a single column indicate significant difference between the treatments at $\mathrm{p} \leq 0.05$.

[CC: conventional control; BM: brown manuring; GM: green manuring; WDS: wet drum seeding; ZT: zero tillage; GM-CLCC-N: green manuring-customized leaf color Chart based Nitrogen; BC: biochar; EC: electrical conductance; TOC: total organic carbon; AN, AP, AK: available nitrogen, phosphorus and potassium; MBC: microbial biomass carbon; MBN: microbial biomass nitrogen; MBP: microbial biomass phosphorus; $\mathrm{C}_{\text {min }}$ : carbon mineralization; $\mathrm{N}_{\text {min }}$ : nitrogen mineralization]

Table 3 Soil Biological properties under different resource conservation practices. 


\begin{tabular}{|c|c|c|c|c|c|c|c|c|c|c|}
\hline \multirow[t]{2}{*}{ Treatment } & DHA & FDA & $\begin{array}{l}\beta \text { - } \\
\text { glucosidase }\end{array}$ & Urease & Cellulase & Invertase & Xylanase & Heterotrophs & Fungus & Actinomycetes \\
\hline & $\begin{array}{l}\left(\mu \mathrm{g} \mathrm{g} \mathrm{g}^{-1} \mathrm{~d}^{-}\right. \\
\left.{ }^{1}\right)\end{array}$ & $\begin{array}{l}\left(\mu g^{-1} d^{-}\right. \\
\left.{ }^{-}\right)\end{array}$ & $\left(\mu \mathrm{g} \mathrm{g} \mathrm{g}^{-1} \mathrm{~d}^{-1}\right)$ & $\begin{array}{l}\left(\mu g^{-1} d^{-}\right. \\
\left.{ }^{1}\right)\end{array}$ & $\begin{array}{l}\left(\mu \mathrm{g} \mathrm{g} \mathrm{g}^{-1} \mathrm{~d}^{-}\right. \\
\left.{ }^{1}\right)\end{array}$ & $\begin{array}{l}\left(\mu g g^{-1} d^{-}\right. \\
\left.{ }^{1}\right)\end{array}$ & $\begin{array}{l}\left(\mu \mathrm{g} \mathrm{g} \mathrm{g}^{-1} \mathrm{~d}^{-}\right. \\
\left.{ }^{1}\right)\end{array}$ & $\left(\log c f u g^{-1}\right)$ & $\begin{array}{l}\text { (Log cfu } \\
\left.\mathrm{g}^{-1}\right)\end{array}$ & $\left(\log c f u g^{-1}\right)$ \\
\hline $\mathrm{CC}$ & $226.8^{f}$ & $83.1^{\mathrm{e}}$ & $49.8^{e}$ & $149.0^{e}$ & $0.31^{\mathrm{g}}$ & $1.73^{d}$ & $1.17^{d}$ & $6.78^{d}$ & $4.52^{\mathrm{cd}}$ & $4.47^{c}$ \\
\hline BM & $294.6^{c}$ & $93.0^{c}$ & $55.2^{\mathrm{c}}$ & $163.1^{\mathrm{c}}$ & $0.63^{d}$ & $2.17^{\mathrm{c}}$ & $1.50^{\mathrm{c}}$ & $6.83 b^{c}$ & $4.59^{b}$ & $4.55^{b c}$ \\
\hline GM & $371.5^{a}$ & $109.1^{\mathrm{a}}$ & $64.0^{a}$ & $186.2^{a}$ & $0.89^{b}$ & $2.40^{\mathrm{a}}$ & $1.67^{b}$ & $6.92^{a}$ & $4.75^{a}$ & $4.72^{\mathrm{a}}$ \\
\hline WDS & $254.7^{e}$ & $87.6^{d}$ & $52.2^{d}$ & $155.1^{d}$ & $0.39^{f}$ & $1.83^{d}$ & $1.23^{\mathrm{d}}$ & $6.79^{c}$ & $4.54^{d}$ & $4.49^{b c}$ \\
\hline $\mathrm{ZT}$ & $275.8^{d}$ & $78.1^{f}$ & $47.0^{f}$ & $141.5^{f}$ & $0.98^{a}$ & $2.50^{a}$ & $1.80^{\mathrm{a}}$ & $6.84^{b}$ & $4.63^{b}$ & $4.59^{b}$ \\
\hline $\begin{array}{l}\text { G M-CLCC- } \\
\mathrm{N}\end{array}$ & $314.2^{\mathrm{b}}$ & $102.3^{b}$ & $60.3^{b}$ & $176.6^{b}$ & $0.84^{c}$ & $2.37^{b}$ & $1.67^{b}$ & $6.90^{\mathrm{a}}$ & $4.72^{\mathrm{a}}$ & $4.69^{a}$ \\
\hline $\mathrm{BC}$ & $258.6^{e}$ & $90.0^{d}$ & $53.7^{\mathrm{cd}}$ & $159.0^{d}$ & $0.56^{e}$ & $2.07^{c}$ & $1.43^{\mathrm{c}}$ & $6.82^{b c}$ & $4.59^{b}$ & $4.54^{b c}$ \\
\hline
\end{tabular}

† Different characters in a single column indicate significant difference between the treatments at $\mathrm{p} \leq 0.05$.

[CC: conventional control; BM: brown manuring; GM: green manuring; WDS: wet drum seeding; ZT: zero tillage; GM-CLCC-N: green manuring-customized leaf color Chart based Nitrogen; BC: biochar; DHA: dehydrogenase activity; FDA: fluorescein di-acetate activity]

\section{Average well color development by using Biolog eco-plates}

Average well color development showed differences in the metabolic reaction rate of microbial communities among resource conservation treatments. The development of colour based an average utilization of carbon sources using Biolog eco-plates usually showed an S-shaped pattern in relation to time during the $120 \mathrm{~h}$ incubation-period (Fig. 2). For the duration of incubation, different sources of carbon mineralization by microbes were significantly higher in green manuring (GM) than other treatments irrespective of the duration of incubation. The AWCD values in control (CC) were the lowest while under green manuring; the values were found to be highest in all the incubation periods (Fig. 2).

The rate of change in microbial metabolic activities was observed maximum at $48 \mathrm{~h}$ of incubation and in the order of GM $>\mathrm{BM}>\mathrm{ZT}>\mathrm{WDS}>\mathrm{GM}+\mathrm{CLCC}-\mathrm{N}>$ $\mathrm{CC}>\mathrm{BC}$. After $48 \mathrm{~h}$, the metabolic activities of all the treatments were reduced significantly, while, the rate of microbial activities were enhanced in all treatments up to $96 \mathrm{~h}$ of incubation and then decreased gradually (Fig. 3).

The AWCD value observed at $72 \mathrm{~h}$ of incubation was also higher $(26.6 \%)$ in green manuring treatment than others. The Shannon index has shown a significantly higher values in GM by $86.9 \%$ as compared to the control treatment and the lowest was recorded under WDS treatment. The Mclntosh index determined from the $72 \mathrm{~h}$ incubation period of Biolog ${ }^{\circledR}$ data was also higher in GM by $29.2 \%$ than that of control. The AWCD, Shannon index and Mclntosh indices indicated a significantly higher microbial activity under GM compared to the RCTs and control (Table 4).

Table 4 The average well colour development (AWCD) and diversity indices of microbial communities (based on $72 \mathrm{~h}$ data from biolog analysis) of the soil under resource conservation.

\begin{tabular}{llll} 
Treatment & AWCD & Shannon Index & Mclntosh index \\
\hline CC & $0.88^{\mathrm{c}}$ & $0.35^{\mathrm{e}}$ & $5.62^{\mathrm{e}}$ \\
\hline BM & $1.10^{\mathrm{ab}}$ & $1.64^{\mathrm{c}}$ & $7.28^{\mathrm{b}}$ \\
\hline GM & $1.20^{\mathrm{a}}$ & $2.70^{\mathrm{a}}$ & $7.94^{\mathrm{a}}$ \\
\hline WDS & $0.89 \mathrm{c}$ & $0.58^{\mathrm{e}}$ & $6.29^{\mathrm{d}}$ \\
\hline ZT & $1.01^{\mathrm{b}}$ & $1.29^{\mathrm{d}}$ & $6.95^{\mathrm{c}}$ \\
\hline G M-CLCC-N & $1.17^{\mathrm{ab}}$ & $2.23^{\mathrm{b}}$ & $7.80^{\mathrm{a}}$ \\
\hline BC & $0.95^{\mathrm{b}}$ & $1.21^{\mathrm{d}}$ & $6.94^{\mathrm{c}}$
\end{tabular}

† Different characters in a single column indicate significant difference between the treatments at $p \leq 0.05$.

[CC: conventional control; BM: brown manuring; GM: green manuring; WDS: wet drum seeding; ZT: zero tillage; GM-CLCC-N: green manuring-customized leaf color Chart based Nitrogen; BC: biochar; AWCD: average well color development]

\section{Utilization of six major carbon substrates under different resource conservation practices}

Use of six major carbon sources such as carboxylic acids (CA), carbohydrates (CB), phenolic compounds (PC), amino acids (AA), polymers (PO), and amines (AM) showed large variations under different resource conservation treatments. Carboxylic acids (CA), carbohydrates (CB) and amino acids (AA) utilization 
was higher in green manuring (GM) followed by GM-CLCC-N treatment and lowest in control. However, relative stable C compounds like, amines (AM), phenolic compounds (PC) and polymers (PO) utilization were found higher in control treatment followed by WDS, ZT and BC (Fig. 4).

The amines and amino acid utilizing microbes were dominant in all the treatments under resource conservation (Fig. 4). The consumption of carbohydrates and carboxylic acids were found to be highest in CC and BM, respectively, whereas BM showed the highest consumption of amines and GM towards amino acids. However, there was no significant difference among all the treatments in the consumption of phenolic compounds and polymers (Fig. 4).

\section{Principal component coupled with biplot analysis}

Biplot analysis of seven treatments showed different spatial distribution on the coordinate axis. The corresponding projective points indicate that the BM, GMCLCC-N treatment plots were in one quadrant and showed significantly utilization of amines (AM). Similarly, GM, ZT in another quadrant which gives strong response to amino acids (AA). Biochar detached from all the treatments, occupied a separate quadrant and gives strong response to carboxylic acids (CA). WDS and CC inhabited in same quadrant, which showed significant utilization of carbohydrates (CB), phenolic compounds (PC) and polymers (PO) (Fig. 5 A). Similarly, biplot analysis of six major groups of specific kinds of carbon sources, such as carboxylic acid; amino acids; amines; carbohydrates, phenolic compounds and polymers were laid at the $1^{\text {st }}, 2^{\text {nd }}, 3^{\text {rd }}$ and $4^{\text {th }}$ quadrant, respectively (Fig. $5 \mathrm{~A}$ ).

PCA was applied to the dataset consisting of seven treatments (BM, BC, CC, GM, GM-CLCC N, WDS and ZT) in three replications having a total of thirty parameters. As shown in Fig. 5 B. PCA explained a total variance of $65 \%$ with PC1 contributing to $51.7 \%$ and PC2 contributing to $13.3 \%$ respectively. The seven treatments has been found to aggregate into definite clusters displayed as elliptical circles over the ordination planes, with the larger symbols in centre of each ellipse representing the mean of three replications. In the first (+/+) quadrant GM-CLCC N and GM treatments are found, in the second (+/-) quadrant ZT treatment is found, in the third quadrant (-/-) BC is found along with WDS treatment and in the fourth quadrant (-/+) CC is found with WDS but having less interaction as compared to BC. The first dimension PC1 could explain the variances of four treatments with GM showing maximum variances followed by CC, WDS and GM-CLCCN. Similarly, the second dimension PC2 could explain the maximum variances of only one treatment ZT. The other two treatments BM and $\mathrm{BC}$ had less contribution on overall variances represented by PCA. Contribution (coefficient values given in parenthesis) of the parameters were higher in DHA (0.915), A (0.912), F (0.910), MBN (0.905), H (0.903), MBP (0.886). As shown in the PCA ordination biplot, it could be inferred these highly correlated parameters to be chiefly associated with GM and GM-CLCC N. The parameters CL (0.849), IN (0.815), XY (0.812), MI (0.808), TOC (0.799), AP (0.783), PC (0.741), PO (0.739), AWCD (0.733), AK (0.726) variances was found to be attributed the ZT treatment. MBC (0.723), AN (0.715), FDA (0.723), BG (0.704), UR (0.703) demonstrated lesser variances and from the ordination biplot could be attributed to GM and GM-CLCCN treatments. The treatments CB (-0.405), AA $(-0.606)$ and $\mathrm{SI}(-0.648)$ showed negative correlation with GM and GM-CLCC N treatments, however was positively correlated with CC treatment followed by WDS. In the second dimension PC2, the components NM (0.730) and CM (0.72b) showed the highest contribution which can be attributed to GM and GMCLCC N treatments. The parameters CA (0.450), EC (0.396) were found to have very low correlation coefficient in first dimension PC1, whose contribution increased in third dimension (0.730). However, only the first two dimensions were taken for analysis.

\section{Principal component coupled with biplot analysis}

Biplot analysis of seven treatments showed different spatial distribution on the coordinate axis. The corresponding projective points indicate that the BM, GMCLCC-N treatment plots were in one quadrant and showed significantly utilization of amines (AM). Similarly, GM, ZT in another quadrant which gives strong response to amino acids (AA). Biochar detached from all the treatments, occupied a separate quadrant and gives strong response to carboxylic acids (CA). WDS and CC inhabited in same quadrant, which showed significant utilization of carbohydrates (CB), phenolic compounds (PC) and polymers (PO) (Fig. 5 A). Similarly, biplot analysis of six major groups of specific kinds of carbon sources, such as carboxylic acid; amino acids; amines; carbohydrates, phenolic compounds and polymers were laid at the $1^{\text {st }}, 2^{\text {nd }}, 3^{\text {rd }}$ and $4^{\text {th }}$ quadrant, respectively (Fig. $5 \mathrm{~A}$ ).

PCA was applied to the dataset consisting of seven treatments (BM, BC, CC, GM, GM-CLCC N, WDS and ZT) in three replications having a total of thirty parameters. As shown in Fig. 5 B. PCA explained a total variance of $65 \%$ with PC1 contributing to $51.7 \%$ and PC2 contributing to $13.3 \%$ respectively. The seven treatments has been found to aggregate into definite clusters displayed as elliptical circles over the ordination planes, with the larger symbols in centre of each ellipse representing the mean of three replications. In the first (+/+) quadrant GM-CLCC N and GM treatments are found, in the second (+/-) quadrant ZT treatment is found, in the third quadrant (-/-) BC is found along with WDS treatment and in the fourth quadrant ( $/ /+)$ CC is found with WDS but having less interaction as compared to BC. The first dimension PC1 could explain the variances of four treatments with GM showing maximum variances followed by $\mathrm{CC}$, WDS and GM-CLCCN. Similarly, the second dimension PC2 could explain the maximum variances of only one treatment ZT. The other two treatments BM and $\mathrm{BC}$ had less contribution on overall variances represented by PCA. Contribution (coefficient values given in parenthesis) of the parameters were higher in DHA (0.915), A (0.912), F (0.910), MBN (0.905), H (0.903), MBP (0.886). As shown in the PCA ordination biplot, it could be inferred these highly correlated parameters to be chiefly associated with GM and GM-CLCC N. The parameters CL (0.849), IN (0.815), XY (0.812), MI (0.808), TOC (0.799), AP (0.783), PC (0.741), PO (0.739), AWCD (0.733), AK (0.726) variances was found to be attributed the ZT treatment. MBC (0.723), AN (0.715), FDA (0.723), BG (0.704), UR (0.703) demonstrated lesser variances and from the ordination biplot could be attributed to GM and GM-CLCCN treatments. The treatments CB (-0.405), AA $(-0.606)$ and $\mathrm{SI}(-0.648)$ showed negative correlation with GM and GM-CLCC N treatments, however was positively correlated with CC treatment followed by WDS. In the second dimension PC2, the components NM (0.730) and CM (0.72b) showed the highest contribution which can be attributed to GM and GMCLCC N treatments. The parameters CA (0.450), EC (0.396) were found to have very low correlation coefficient in first dimension PC1, whose contribution increased in third dimension (0.730). However, only the first two dimensions were taken for analysis.

\section{Discussion}

Impact of resource conservation on soil physical properties 
In the present study, higher $\mathrm{pH}$ was recorded under green manuring and zero tillage treatments, as compared to other treatments. Addition of Sesbania and rice residues increased the soil pH and thereby reduces the exchangeable acidity (Opala et al., 2012). Exogenous application of manure might buffer the soil acidity which changed the soil pH to a slightly higher value by defusing some free $\mathrm{H}^{+}$ions (Kumar et al., 2017). Chemical fertilizers have acidifying effects that decrease in soil pH of conventional practice (Hati et al., 2008).

\section{Impact of resource conservation on soil carbon and nitrogen fractions}

Total organic carbon (TOC) was recorded higher in organic amendment treatments (GM, BM, ZT and BC) compared to CC. Combined application of inorganic fertilizer and manure enhanced the TOC under paddy soil environment (Mohanty et al., 2013; Dossou-Yovo et al., 2016; Kumar et al., 2017) .

Our findings also showed that resource conservation practices have higher microbial biomass carbon (MBC) content compared to CC (Table 2). Balanced nutrient inputs and supplemented by resource conservation practices play a crucial role for enhancement of soil organic carbon (SOC) and MBC (Cookson et al., 2007; Balachandar et al., 2014). The higher content of MBC in green manuring treatment might be due to presence of higher shoot and root biomass turn-

Table 5 Correlation matrix analysis with different variables of microbial indicators under resource conservation practices.

\begin{tabular}{|c|c|c|c|c|c|c|c|c|c|c|c|c|c|}
\hline & MBC & MBN & MBP & DHA & FDA & BGL & URE & CEL & INV & $X Y L$ & HET & FUN & ACT \\
\hline MBC & 1.00 & & & & & & & & & & & & \\
\hline MBN & $0.710^{\mathrm{ns}}$ & 1.00 & & & & & & & & & & & \\
\hline MBP & $0.724^{\mathrm{ns}}$ & $0.948^{\star \star}$ & 1.00 & & & & & & & & & & \\
\hline DHA & $0.736^{\mathrm{ns}}$ & $0.929^{* *}$ & $0.974^{\star *}$ & 1.00 & & & & & & & & & \\
\hline FDA & $0.590^{\mathrm{ns}}$ & $0.792^{*}$ & $0.659^{\text {ns }}$ & $0.727^{\mathrm{ns}}$ & 1.00 & & & & & & & & \\
\hline BGL & $0.591^{\mathrm{ns}}$ & $0.794^{*}$ & $0.662^{\mathrm{ns}}$ & $0.729^{\text {ns }}$ & $1.000^{\star *}$ & 1.00 & & & & & & & \\
\hline URE & $0.590^{\mathrm{ns}}$ & $0.793^{*}$ & $0.661^{\mathrm{ns}}$ & $0.728^{\text {ns }}$ & $1.000^{\star \star}$ & $1.000^{\star *}$ & 1.00 & & & & & & \\
\hline CEL & $0.543^{\text {ns }}$ & $0.760^{*}$ & $0.729^{\text {ns }}$ & $0.720^{\mathrm{ns}}$ & $0.401^{\mathrm{ns}}$ & $0.402^{\mathrm{ns}}$ & $0.399^{\mathrm{ns}}$ & 1.00 & & & & & \\
\hline INV & $0.569^{\mathrm{ns}}$ & $0.752^{\mathrm{ns}}$ & $0.733^{\mathrm{ns}}$ & $0.709^{\text {ns }}$ & $0.367^{\mathrm{ns}}$ & $0.368^{\mathrm{ns}}$ & $0.365^{\mathrm{ns}}$ & $0.996^{\star \star}$ & 1.00 & & & & \\
\hline$X Y L$ & $0.554^{\mathrm{ns}}$ & $0.718^{n s}$ & $0.710^{\text {ns }}$ & $0.684^{\mathrm{ns}}$ & $0.308^{\text {ns }}$ & $0.308^{\text {ns }}$ & $0.306^{\mathrm{ns}}$ & $0.992^{\star \star}$ & $0.998^{\star *}$ & 1.00 & & & \\
\hline HET & $0.686^{\mathrm{ns}}$ & $0.916^{\star \star}$ & $0.867^{*}$ & $0.926^{\star \star}$ & $0.763^{*}$ & $0.764^{*}$ & $0.763^{*}$ & $0.842^{*}$ & $0.814^{*}$ & $0.787^{*}$ & 1.00 & & \\
\hline FUN & $0.691^{\mathrm{ns}}$ & $0.915^{\star \star}$ & $0.872^{*}$ & $0.927^{\star \star}$ & $0.745^{\mathrm{ns}}$ & $0.746^{\mathrm{ns}}$ & $0.745^{\mathrm{ns}}$ & $0.858^{*}$ & $0.832^{*}$ & $0.807^{*}$ & $0.999^{\star \star}$ & 1.00 & \\
\hline ACT & $0.680^{\mathrm{ns}}$ & $0.914^{\star *}$ & $0.872^{*}$ & $0.925^{\star \star}$ & $0.738^{\text {ns }}$ & $0.739^{\text {ns }}$ & $0.737^{\mathrm{ns}}$ & $0.866^{*}$ & $0.840^{*}$ & $0.815^{\star}$ & $0.999^{\star \star}$ & $1.000^{\star \star}$ & 1.00 \\
\hline AWCD & $0.786^{*}$ & $0.801^{*}$ & $0.907^{\star \star}$ & $0.872^{*}$ & $0.430^{\mathrm{ns}}$ & $0.432^{\text {ns }}$ & $0.429^{\mathrm{ns}}$ & $0.807^{*}$ & $0.833^{*}$ & $0.827^{*}$ & $0.773^{*}$ & $0.790^{*}$ & $0.792^{*}$ \\
\hline RAWCD & $-0.219^{n s}$ & $-0.782^{*}$ & $-0.803^{*}$ & $-0.731^{\mathrm{ns}}$ & $-0.513^{\text {ns }}$ & $-0.514^{\text {ns }}$ & $-0.513^{n s}$ & $-0.627^{n s}$ & $-0.619^{n s}$ & $-0.589^{n s}$ & $-0.646^{\mathrm{ns}}$ & $-0.650^{\mathrm{ns}}$ & $-0.661^{\mathrm{ns}}$ \\
\hline SNI & $0.848^{*}$ & $0.798^{*}$ & $0.853^{*}$ & $0.858^{*}$ & $0.584^{\mathrm{ns}}$ & $0.585^{\mathrm{ns}}$ & $0.581^{\mathrm{ns}}$ & $0.802^{*}$ & $0.818^{*}$ & $0.800^{*}$ & $0.816^{*}$ & $0.830^{\star}$ & $0.829^{*}$ \\
\hline $\mathrm{MCl}$ & $0.830^{*}$ & $0.925^{\star \star}$ & $0.901^{\star \star}$ & $0.907^{\star \star}$ & $0.754^{\mathrm{ns}}$ & $0.755^{\star}$ & $0.753^{\mathrm{ns}}$ & $0.833^{*}$ & $0.835^{\star}$ & $0.804^{*}$ & $0.915^{\star \star}$ & $0.921^{\star \star}$ & $0.920^{\star \star}$ \\
\hline RY & $0.767^{*}$ & $0.938^{\star *}$ & $0.995^{\star \star}$ & $0.961^{\star *}$ & $0.646^{\mathrm{ns}}$ & $0.648^{\text {ns }}$ & $0.647^{\mathrm{ns}}$ & $0.696^{\mathrm{ns}}$ & $0.706^{\mathrm{ns}}$ & $0.684^{\mathrm{ns}}$ & $0.837^{\star}$ & $0.842^{*}$ & $0.841^{*}$ \\
\hline
\end{tabular}

† ns: non-significant at $p \leq 0.05$ or $p \leq 0.01$. ${ }^{*}$ Correlation is significant at $p \leq 0.01 .{ }^{*}$ Correlation is significant at $p \leq 0.05$.

[DHA: dehydrogenase activity; FDA: fluorescein di-acetate activity; $\beta$-glu: $\beta$-glucosidase; URE: urease activity; CEL: cellulase activity; INV: invertase activity; XYL: xylanase activity; HET: heterotrophs; FUN: fungus; ACT: actinomycetes; AWCD: average well color development; RAWCD: rate of average well color development; SNI: Shannon index; MCI: Mcintosh index; RY: relative yield]

Table 6 Stepwise regression analysis with different variables of microbial indicators under different resource conservation practices. 


\begin{tabular}{|c|c|c|c|}
\hline Dependents & Variable related & $\mathrm{R}^{2}$ & $\begin{array}{l}\text { Significant } \\
\text { level }(p)\end{array}$ \\
\hline MBC & $\begin{array}{l}\text { MBN, MBP, DHA, FDA, } \beta \text {-Glucosidase, Urease, Heterotrophs, Fungus, Actinomycetes, Cmin, Nmin, AWCD, Shannon } \\
\text { index, Mclntosh Index }\end{array}$ & 0.999 & $\leq 0.000$ \\
\hline MBN & MBC, FDA, $\beta$-Glucosidase, Urease, Cmin, Nmin, Shannon index & 0.996 & $\leq 0.000$ \\
\hline \multirow[t]{2}{*}{ MBP } & Cellulase, Invertase, Xylanase, Cmin, Nmin, AWCD, Mclntosh Index, & 0.949 & $\leq 0.000$ \\
\hline & TOC, MBC, MBN, Ntot, AN, AP, AK & & \\
\hline \multirow[t]{2}{*}{ Heterotrophs } & Cmin, Nmin, AWCD, Shannon index, MBC, MBN, MBP, DHA, FDA, & 0.998 & $\leq 0.000$ \\
\hline & $\beta$-Glucosidase, Urease, Cellulase, Invertase & & \\
\hline Actinomycetes & $\begin{array}{l}\text { MBC, MBN, MBP, DHA, FDA, } \beta \text {-Glucosidase, Urease, Cellulase, Invertase, Xylanase, Heterotrophs, Fungus, } \\
\text { Actinomycetes, Cmin, Nmin, TOC, Ntot, AN, AP, AK, AWCD, Mclntosh Index }\end{array}$ & 0.998 & $\leq 0.001$ \\
\hline Fungus & Cmin, Nmin, Shannon index, MBC, AN, Heterotrophs & 0.998 & $\leq 0.000$ \\
\hline \multirow[t]{2}{*}{ AWCD } & Mclntosh Index, TOC, MBC, Ntot, AP, AK, MBP, DHA, Cellulase, & 0.996 & $\leq 0.000$ \\
\hline & Invertase, Xylanase, Heterotrophs, Fungus & & \\
\hline $\begin{array}{l}\text { Shannon } \\
\text { index }\end{array}$ & $\begin{array}{l}\text { MBC, MBN, MBP, DHA, FDA, } \beta \text {-Glucosidase, Urease, Cellulase, Invertase, Xylanase, Heterotrophs, Fungus, } \\
\text { Actinomycetes }\end{array}$ & 0.972 & $\leq 0.002$ \\
\hline $\begin{array}{l}\text { Mclntosh } \\
\text { Index }\end{array}$ & $\begin{array}{l}\text { TOC, MBC, Ntot, AN, MBP, DHA, } \beta \text {-Glucosidase, Urease, Cellulase, Invertase, Xylanase, Heterotrophs, Fungus, } \\
\text { Actinomycetes }\end{array}$ & 0.887 & $\leq 0.002$ \\
\hline
\end{tabular}

[DHA: dehydrogenase activity; FDA: fluorescein di-acetate activity; $\beta$-glu: $\beta$-glucosidase; URE: urease activity; CEL: cellulase activity; INV: invertase activity; XYL: xylanase activity; HET: heterotrophs; FUN: fungus; ACT: actinomycetes; AWCD: average well color development; RAWCD: rate of average well color development; SNI: Shannon index; $\mathrm{MCl}$ : Mcintosh index; RY: relative yield]

over (Mandal et al., 2007; Liu et al., 2013; Shahid et al., 2017), which significantly increases carbon input (Manna et al., 2005; Lal, 2015). Soil microbial biomass carbon also controls nutrient cycling soil organic matter decomposition, thereby plays a vital role in sustaining soil health. Green manuring and rice residue provide a potent source of $\mathrm{C}$ nutrients that facilitates the growth of soil microorganism.

Our findings also showed that resource conservation practices have higher microbial biomass carbon (MBC) content compared to CC (Table 2). Balanced nutrient inputs and supplemented by resource conservation practices play a crucial role for enhancement of soil organic carbon (SOC) and MBC (Cookson et al., 2007; Balachandar et al., 2014). The higher content of MBC in green manuring treatment might be due to presence of higher shoot and root biomass turnover (Mandal et al., 2007; Liu et al., 2013; Shahid et al., 2017), which significantly increases carbon input (Manna et al., 2005; Lal, 2015). Soil microbial biomass carbon also controls nutrient cycling soil organic matter decomposition, thereby plays a vital role in sustaining soil health. Green manuring and rice residue provide a potent source of $\mathrm{C}$ nutrients that facilitates the growth of soil microorganism.

Resource conservation treatments enhances mineralization rate ( $\mathrm{C}$ and $\mathrm{N})$, by enhancing microbial growth and thereby enhanced the decomposition of crop residues (roots and stubbles) in the soil (Muhammad et al., 2014). Incorporation of green manuring and brown manuring, adoption of zero tillage improve soil aggregation and aggregate associate carbon, thereby facilitating SOC build up (Gupta et al., 2014; M.-Y. Liu et al., 2014; Shahid et al., 2017).

The green manuring provided a simple form of organic $\mathrm{C}$ to sustaining the microbial growth and have potential for maintaining higher level of MBC (Mandal et al., 2007). Microbial biomass (C, N and P) increased significantly with the addition of leguminous residue has low C:N ratio as compared to crop residue has reach high C:N ratios (Weber et al., 2008; Yu et al., 2015).

\section{Impact of resource conservation on Soil enzymatic activities}

Compared to rice residue, green manuring can easily decomposed by the soil microorganisms to produce simple sugar compounds, which enhances soil enzyme activities (Bhattacharyya et al., 2012). Dehydrogenase activity mostly depends on the soil microbial respiration, highest activities of which occurred under green manuring treatment also recording highest microbial population. Higher C, N substrate level (Bhattacharyya et al., 2013b) and microbial population (Kumar et al., 2017) in green manuring plots, might have promoted the soil enzymatic activities. More organic matter in amended soil contributes more $\mathrm{C}$ source for microorganisms resulting in higher C-mineralization and enzymatic activities (Tian et al., 2016).

\section{Effect of resource conservation technology on microbial population}

The population of total aerobic heterotrophic bacteria (AHB), fungi, and actinomycetes were significantly higher in resource conservation practices than that of control, which publicized that some specific individual nutrients (Ramirez-Villanueva et al., 2015) present in RCTs treatments might have increased total soil microbial populations. Long-term resource conservation practices in rice soil enhance fungal and bacterial populations due to favourable substrate base (Six et al., 2006). Organic amendments provide necessary C, N and energy for microbial growth and reproduction (Huang et al., 2010). Organic manure applications significantly changes bacteria, actinomycetes and fungi population in soils as compared to the soils treated with mineral fertilizer (Dong et al., 2014).

\section{Effect of resource conservation technology on microbial diversity}


Several investigations use to find out the functional diversity of soil-microbes in rhizosphere using Biolog ${ }^{\circledR}$ eco-plates (Xu and Ge, 2015). The variation in the microbial community functions due to their different metabolic activities were indicated according to optical density (OD) values (colour change) at every reaction holes that utilizes 31 kind of different C-sources (Calbrix et al., 2005). The sigmoid curves of AWCD were found in all the treatments except control in all the incubation period (i.e. 0-120 h), almost resembles the S-arch of bacterial growth (Guanghua et al., 2008), which indicated that the richness of microbial communities (Zhong and Cai, 2007) in those treatments, however, the conventional control treatment having linear curve indicated the low microbial richness (Guanghua et al., 2008).

In the present study, the increasing average well color development (AWCD) values under the different treatments was in the order of GM > GM-CLCC-N > BM > $\mathrm{ZT}>\mathrm{BC}>\mathrm{WDS}>\mathrm{CC}$. The highest rate of AWCD observed in green manuring and the lowest was under CC could be due to increased soil microbial biomass (C, $\mathrm{N}$ and $\mathrm{P}$ ) in GM that enriched the biomass addition and microbial activities (Gu et al., 2009). Combined application of most diverse resources of organic + mineral fertilizers could greatly increase in microbial biomass and their activity which enhances nutrient availability in soils (Chang et al., 2016). It was also recommended that adjustment of the appropriate proportion of specific organic amendments such as farmyard manure, green manure, rice straw, etc. can enhance the fertility through shifting of microbial community in rice soil under different fertilization practices (Wanjiru et al., 2015).

The higher metabolic activities of active microbial communities utilizing the C-substrates within $48 \mathrm{~h}$, resulted the decrease in the rate of AWCD after $48 \mathrm{~h}$ of incubation in different resource conservation treatments. Since, the metabolic activity was reduced under all the treatments after $72 \mathrm{~h}$; hence the analysis of soil microbial functional diversity was done at this particular time. Significantly higher AWCD in green manuring treatment compared to other treatments indicated that addition of biomass (green manure, rice residue, biochar) played crucial role in microbial dynamics and also shifting the soil microbial community structure. Shannon index of green manuring treated plots was significantly higher $(p \leq 0.05)$ which implied that the species richness and evenness of soil microbial communities in that particular treatment might be different from other treatments. The increasing order of Shannon index in GM, GM+CLCC-N and BM indicated that soil microbial communities were affected by biomass addition which accounts for rapid increase in microbial population (Baldrian et al., 2012) rather than their diversity (Guanghua et al., 2008; Moharana et al., 2012; Nayak et al., 2012). Resource conservation treatments could enhance the accumulation of organic which altered the pattern of potential carbon utilization and increased the Shannon, Mclntosh and AWCD indices values (Chinnadurai et al., 2014). The biplot analysis (Fig. 5A) indicated the separation of RCT treatments (biomass added) from WDS and conventional control (chemical fertilizer) treatment which supported that treatments receiving green manuring, brown manuring, rice residue and biochar could have a greater influence on microbial functional diversity than conventional control.

It has been observed that the utilization of six major carbon groups by microbial communities within and between different treatments showed a unique pattern. Consumption of carbohydrates, amino acids and carboxylic acid were higher with application of green manuring and brown manuring, which indicates that microorganisms present in that treatments were more active towards easily decomposable carbon sources than other treatments. Addition of Lupin green manure (organic $\mathrm{N}$ source) resulted in significantly higher microbial biomass and activity as compared to control soils (Preethi et al., 2013). Kumar et al. (2017) reported that at the early stages, microbial communities utilized simple sugars as major substrates, whereas complex C-substrates were utilized at later stages, which indicated that shifting of the microbial community based on presence and/or absence of available nutrients. However, microbes utilize complex C substrates (phenolic compounds, amines, polymers) more in control due to less microbial activities (An et al., 2014). Variation in Biolog patterns was mainly due to applications of different biomass and could be explained by the second quadrant and third quadrant of principal components (PCs). The present study revealed that resource conservation (chemical fertilizer + organic matter) practices significantly enhanced the soil biological-activity which promoted the microorganisms to utilise the different $\mathrm{C}$ sources.

\section{Correlation and Stepwise regression of microbial indicators}

Highly significant positive correlations existed among MBC with soil enzymatic activities and microbial populations, which suggested that MBC content, increased simultaneously to give rise to enzymatic activities and microbial population in the soil. The enzyme activities were highly correlated with $\mathrm{C} / \mathrm{N}$ fractions; microbial populations, Shannon index and McIntosh index because their activities were increased considerable by increasing addition of labile $\mathrm{N}$ and C source (Bhattacharyya et al., 2013a; Zhu et al., 2014; Chaudhary et al., 2017).

The AWCD, Shannon index and Mclntosh were highly correlated with microbial biomass (C, N \& P), enzymatic activities and microbial populations, whereas, they were not correlated with each other except AWCD (Table 4). Shannon index provides information about the spread/distribution of C source utilization by microbes and affected more by species richness (Zhang et al., 2014; Guo et al., 2016; Tautges et al., 2016). Our study suggested that the decreased in Shannon index was due to dominance of common species of microorganisms as well as MBC, MBN and MBP which were increased along with the increasing $\mathrm{C}_{\min }$ in the green manuring treated soil.

\section{Conclusions}

This study demonstrated the Biolog based technique to differentiate the functional soil microbial diversities under different resource conservation practices. The present study is implying that microbial community present in biomass amended treatments (GM, GM-CLCC N, BM) utilize available or simple form of carbons for their growth (carbohydrates, amino acids and carboxylic acid), whereas microorganisms prevalent in the treatments of chemical fertilizers alone preferably utilize stable $\mathrm{C}$ compounds (phenolic compounds, amines, polymers) due to unavailability of labile $\mathrm{C}$ sources. It indicates that biomass amended treatments (GM, GM-CLCC N, BM) could supply good amount of labile C sources on real time basis for microbial activity that may protect the stable C fraction in soil, hence could support higher build-up of $C$ in long run. Therefore, various resource conservation practices that enhance the microbial biomass, enzymatic activities and diversity at the same time maintaining or enhancing the yield need to be adopted suiting to the local condition.

\section{Declarations}




\section{Acknowledgements}

We thankfully acknowledge Director NRRI and NRRI-Institute Project No. 2.6 entitled "Resource Conservation Technologies and Conservation Agriculture for sustainable rice production" for providing the field and laboratory facilities for conducting this work. Some portions of this manuscript are part of the doctoral research findings of Pradeep K. Dash.

\section{Conflict of Interest}

The authors declare that they have no conflict of interest.

\section{References}

Abera G, Wolde-meskel E, Bakken LR. 2012. Carbon and nitrogen mineralization dynamics in different soils of the tropics amended with legume residues and contrasting soil moisture contents. Biology and Fertility of Soils, 48, 51-66. doi:10.1007/s00374-011-0607-8

Acosta-martínez V, Lascano R, Calderón F, Booker JD, Zobeck TM, Upchurch DR. 2011. Dryland cropping systems influence the microbial biomass and enzyme activities in a semiarid sandy soil. Biology and Fertility of Soils, 47, 655-667. doi:10.1007/s00374-011-0565-1

Adam G, Duncan H. 2001. Development of a sensitive and rapid method for the measurement of total microbial activity using fluorescein diacetate (FDA) in a range of soils. Soil Biology and Biochemistry, 33, 943-951. doi:10.1016/S0038-0717(00)00244-3

An N, Lee S, Cho J, Lee B, Shin, J, Ok J, Kim S. 2014. Effects of Long-Term Fertilization on Microbial Diversity in Upland Soils Estimated by Biolog Ecoplate and DGGE. Korean Journal of Soil Science and Fertilizer, 47, 451-456.

Anderson TH. 2003. Microbial eco-physiological indicators to asses soil quality. Agriculture, Ecosystem \& Environment, 98, 285-293. doi:10.1016/S01678809(03)00088-4

Badiane NNY, Chotte JL, Pate E, Masse D, Rouland C. 2001. Use of soil enzyme activities to monitor soil quality in natural and improved fallows in semi-arid tropical regions. Applied Soil Ecology, 18, 229-238. doi:10.1016/S0929-1393(01)00159-7

Balachandar D, Doud MS, Schneper L, Mills D, Mathee K. 2014. Long-Term Organic Nutrient Management Fosters the Eubacterial Community Diversity in the Indian Semi-arid Alfisol as Revealed by Length Heterogeneity-PCR. Communications in Soil Science and Plant Analysis, 45, 189203. doi:10.1080/00103624.2013.841919

Baldrian P, Kolařík M, Štursová M, Kopecký J, Valášková V, Větrovský T, Žifčáková L, Šnajdr J, Rídl J, Vlček Č, Vořǐšková J. 2012. Active and total microbial communities in forest soil are largely different and highly stratified during decomposition. The ISME journal, 6, 248-258. doi:10.1038/ismej.2011.95

Baudoin E, Philippot L, Chèneby D, Chapuis-Lardy L, Fromin N, Bru D, Rabary B, Brauman A. 2009. Direct seeding mulch-based cropping increases both the activity and the abundance of denitrifier communities in a tropical soil. Soil Biology and Biochemistry, 41, 1703-1709. doi:10.1016/j.soilbio.2009.05.015

Benbi DK, Sharma S, Toor AS, Brar K, Sodhi GPS, Garg AK. 2016. Differences in soil organic carbon pools and biological activity between organic and conventionally managed rice-wheat fields. Organic Agriculture, 8, 1-4. doi:10.1007/s13165-016-0168-0

Bhattacharyya P, Nayak AK, Mohanty S, Tripathi R, Shahid M, Kumar A, Raja R, Panda BB, Roy KS, Neogi S, Dash PK. 2013a. Greenhouse gas emission in relation to labile soil $\mathrm{C}, \mathrm{N}$ pools and functional microbial diversity as influenced by 39 years long-term fertilizer management in tropical rice. Soil \& Tillage Research, 129, 93-105. doi:10.1016/j.still.2013.01.014

Bhattacharyya P, Neogi S, Roy KS, Dash PK, Tripathi R, Rao KS. 2013b. Net ecosystem $\mathrm{CO}_{2}$ exchange and carbon cycling in tropical lowland flooded rice ecosystem. Nutrient Cycling in Agroecosystems, 95, 133-144. doi:10.1007/s10705-013-9553-1

Bhattacharyya P, Roy KS, Neogi S, Adhya TK, Rao KS, Manna MC. 2012b. Effects of rice straw and nitrogen fertilization on greenhouse gas emissions and carbon storage in tropical flooded soil planted with rice. Soil \& Tillage Research, 124, 119-130. doi:10.1016/j.still.2012.05.015

Bhattacharyya P, Roy KS, Neogi S, Chakravorti SP, Behera KS, Das KM, Bardhan S, Rao KS. 2012a. Effect of long-term application of organic amendment on C storage in relation to global warming potential and biological activities in tropical flooded soil planted to rice. Nutrient Cycling in Agroecosystems, $94,273-$ 285. doi:10.1007/s10705-012-9540-y

Bray RH, Kurtz LT. 1945. Determination of total organic and available forms of phosphorus in soils. Soil Science, 59, 39-46.

Calbrix R, Laval K, Barray S. 2005. Analysis of the potential functional diversity of the bacterial community in soil: A reproducible procedure using sole-carbonsource utilization profiles. European Journal of Soil Biology, 41, 11-20. doi:10.1016/j.ejsobi.2005.02.004

Casida LE, Klein DA, Santoro T. 1964. Soil Dehydrogenase Activity. Soil Science, 98, 371-376. doi:10.1097/00010694-196412000-00004

Chang EH, Chen TH, Tian G, Chiu CY. 2016. The effect of altitudinal gradient on soil microbial community activity and structure in moso bamboo plantations. Applied Soil Ecology, 98, 213-220. doi:10.1016/j.apsoil.2015.10.018 
Chaudhary S, Dheri GS, Brar BS. 2017. Long-term effects of NPK fertilizers and organic manures on carbon stabilization and management index under ricewheat cropping system. Soil \& Tillage Research, 166, 59-66. doi:10.1016/j.still.2016.10.005

Chen C, Zhang J, Lu M, Qin C, Chen Y, Yang L, Huang Q, Wang J, Shen Z, Shen Q. 2016. Microbial communities of an arable soil treated for 8 years with organic and inorganic fertilizers. Biology and Fertility of Soils, 52, 455-467. doi:10.1007/s00374-016-1089-5

Chinnadurai C, Gopalaswamy G, Balachandar D. 2014. Impact of long-term organic and inorganic nutrient managements on the biological properties and eubacterial community diversity of the Indian semi-arid Alfisol. Archives of Agronomy and Soil Science, 60, 531-548. doi:10.1080/03650340.2013.803072

Choi KH, Dobbs FC. 1999. Comparison of two kinds of Biolog microplates (GN and ECO) in their ability to distinguish among aquatic microbial communities. Journal of Microbiological Methods, 36, 203-213. doi:10.1016/S0167-7012(99)00034-2

Choudhury SG, Srivastava S, Singh R, Chaudhari SK, Sharma DK, Singh SK, Sarkar D. 2014. Tillage and residue management effects on soil aggregation, organic carbon dynamics and yield attribute in rice-wheat cropping system under reclaimed sodic soil. Soil \& Tillage Research, 136, 76-

83. doi:10.1016/j.still.2013.10.001

Cookson WR, Osman M, Marschner P, Abaye DA, Clark I, Murphy DV, Stockdale EA, Watson CA. 2007. Controls on soil nitrogen cycling and microbial community composition across land use and incubation temperature. Soil Biology and Biochemistry, 39, 744-756. doi:10.1016/j.soilbio.2006.09.022

Dash PK, Bhattacharyya P, Shahid M, Roy KS, Swain CK, Tripathi R, Nayak AK. 2017. Soil \& Tillage Research Low carbon resource conservation techniques for energy savings, carbon gain and lowering GHGs emission in lowland transplanted rice. Soil \& Tillage Research, 174, 45-

57. doi.org/10.1016/j.still.2017.06.001

Dong W, Zhang X, Dai X, Fu X, Yang F. 2014. Changes in soil microbial community composition in response to fertilization of paddy soils in subtropical China. Applied Soil Ecology, 84, 140-147. doi:10.1016/j.apsoil.2014.06.007

Dossou-Yovo ER, Brüggemann N, Ampofo E, Igue AM, Jesse N, Huat J, Agbossou EK. 2016. Combining no-tillage, rice straw mulch and nitrogen fertilizer application to increase the soil carbon balance of upland rice field in northern Benin. Soil \& Tillage Research, 163, 152-159. doi:10.1016/j.still.2016.05.019

Eivazi F, Tabatabai M. 1988 Glucosidases and Galacosidases in Soils. Soil Biology and Biochemistry, 20, 601-606. doi.org/10.1016/0038-0717(88)90141-1

García-Gil JC, Plaza C, Soler-Rovira P, Polo A. 2000. Long-term effects of municipal solid waste compost application on soil enzyme activities and microbial biomass. Soil Biology and Biochemistry, 32, 1907-1913. doi:10.1016/S0038-0717(00)00165-6

Gu Y, Zhang X, Tu S, Lindström K. 2009. Soil microbial biomass, crop yields, and bacterial community structure as affected by long-term fertilizer treatments under wheat-rice cropping. European Journal of Soil Biology, 45, 239-246. doi:10.1016/j.ejsobi.2009.02.005

Guanghua W, Junjie L, Xiaoning Q, Jian J, Yang W, Xiaobing L. 2008. Effects of fertilization on bacterial community structure and function in a black soil of Dehui region estimated by Biolog and PCR-DGGE methods. Acta Ecologica Sinica, 28, 220-226. doi:10.1016/S1872-2032(08)60023-2

Guo L, Zheng S, Cao C, Li C. 2016. Tillage practices and straw-returning methods affect topsoil bacterial community and organic C under a rice-wheat cropping system in central China. Scientific Reports, 6, 33155. doi:10.1038/srep33155

Hartmann M, Fliessbach A, Oberholzer HR, Widmer F. 2006 Ranking the magnitude of crop and farming system effects on soil microbial biomass and genetic structure of bacterial communities. FEMS Microbiology Ecology, 57, 378-388. doi:10.1111/j.1574-6941.2006.00132.x

Hati KM, Swarup A, Dwivedi AK, Misra AK, Bandyopadhyay KK. 2007. Changes in soil physical properties and organic carbon status at the topsoil horizon of a vertisol of central India after 28 years of continuous cropping, fertilization and manuring. Agriculture, Ecosystem \& Environment, 119, 127-

134. doi:10.1016/j.agee.2006.06.017

Hati KM, Swarup A, Mishra B, Manna MC, Wanjari RH, Mandal KG, Misra AK. 2008. Impact of long-term application of fertilizer, manure and lime under intensive cropping on physical properties and organic carbon content of an Alfisol. Geoderma, 148, 173-179. doi:10.1016/ j.geoderma.2008.09.015

Huang DL, Zeng GM, Feng CL, Hu S, Lai C, Zhao MH, Su FF, Tang L, Liu HL. 2010. Changes of microbial population structure related to lignin degradation during lignocellulosic waste composting. Bioresource Technology, 101, 4062-4067. doi:10.1016/j.biortech. 2009.12.145

Jacobsen CS, Hjelmsø MH. 2014. Science Direct Agricultural soils , pesticides and microbial diversity. Current Opinion in Biotechnology, 27, 1520. doi:10.1016/j.copbio.2013.09.003

Kibblewhite MG, Ritz K, Swift MJ. 2007. Soil health in agricultural systems. Philosophical Transactions of the Royal Society B: Biological Sciences, 363, 685701. doi:10.1098/rstb.2007.2178

Kumar U, Shahid M, Tripathi R, Mohanty S, Kumar A, Bhattacharyya P, Lal B, Gautam P, Raja R, Panda BB, Jambhulkar NN. 2017. Variation of functional diversity of soil microbial community in sub-humid tropical rice-rice cropping system under long-term organic and inorganic fertilization. Ecological Indicators, 73, 536-543. doi:10.1016/j.ecolind.2016.10.014

Page $12 / 18$ 
Ladha JK, Dawe D, Pathak H, Padre AT, Yadav RL et al. 2003. How extensive are yield declines in long-term rice-wheat experiments in Asia? Field Crops Research, 81, 159-180. doi:10.1016/S0378-4290(02)00219-8

Lal R. 2004. Soil carbon sequestration to mitigate climate change. Geoderma, 123, 1-22. doi:10.1016/j.geoderma.2004.01.032

Lal R. 2015. Sequestering carbon and increasing productivity by conservation agriculture. Journal of Soil and Water Conservation, 70, 55A62A. doi:10.2489/jswc.70.3.55A

Li PP, Wang XJ, Yuan XF, Wang XF, Cao YZ, Cui ZJ. 2011. Screening of a composite microbial system and its characteristics of wheat straw degradation. Agricultural Sciences in China, 10, 1586-1594. doi:10.1016/S1671-2927(11)60155-7

Lienhard P, Tivet F, Chabanne A, Dequiedt S, Lelièvre M et al. 2013. No-till and cover crops shift soil microbial abundance and diversity in Laos tropical grasslands. Agronomy for Sustainable Development, 33, 375-384. doi:10.1007/s13593-012-0099-4

Liu E, Teclemariam SG, Yan C, Yu J, Gu R, Liu S, He W, Liu Q. 2014. Long-term effects of no-tillage management practice on soil organic carbon and its fractions in the northern China. Geoderma, 213, 379-384. doi:10.1016/j.geoderma.2013.08.021

Liu E, Yan C, Mei X, Zhang Y, Fan T. 2013. Long-term effect of manure and fertilizer on soil organic carbon pools in dryland farming in northwest China. PloS one, 20, 8(2), e56536. doi:10.1371/journal.pone.0056536

Liu MY, Chang QR, Qi YB, Liu J, Chen T. 2014. Aggregation and soil organic carbon fractions under different land uses on the tableland of the Loess Plateau of China. Catena, 115, 19-28. doi:10.1016/j.catena.2013.11.002

Mandal A, Patra AK, Singh D, Swarup A, Ebhin Masto R. 2007. Effect of long-term application of manure and fertilizer on biological and biochemical activities in soil during crop development stages. Bioresource Technology, 98, 3585-3592. doi:10.1016/ j.biortech.2006.11.027

Manna MC, Swarup A, Wanjari RH, Ravankar HN, Mishra B et al. 2005. Long-term effect of fertilizer and manure application on soil organic carbon storage, soil quality and yield sustainability under sub-humid and semi-arid tropical India. Field Crops Research, 93, 264-280. doi:10.1016/j.fcr.2004.10.006

Min W, Guo H, Zhang W, Zhou G, Ma L, Ye J, Liang Y, Hou Z. 2016. Response of soil microbial community and diversity to increasing water salinity and nitrogen fertilization rate in an arid soil. Acta Agriculturae Scandinavica, Section B-Soil \& Plant Science, 66, 117-126. doi:10.1080/ 09064710.2015.1078838

Mohanty S, Nayak AK, Kumar A, Tripathi R, Shahid M et al. 2013. Carbon and nitrogen mineralization kinetics in soil of rice-rice system under long term application of chemical fertilizers and farmyard manure. European Journal of Soil Biology, 58, 113-121. doi:10.1016/ j.ejsobi.2013.07.004

Moharana PC, Sharma BM, Biswas DR, Dwivedi BS, Singh RV. 2012. Long-term effect of nutrient management on soil fertility and soil organic carbon pools under a 6-year-old pearl millet-wheat cropping system in an Inceptisol of subtropical India. Field Crops Research, 136, 32-41. doi:10.1016/j.fcr.2012.07.002

Moscatelli MC, Lagomarsino A, Garzillo AM, Pignataro A, Grego S. 2012. $\beta$-Glucosidase kinetic parameters as indicators of soil quality under conventional and organic cropping systems applying two analytical approaches. Ecological Indicators, 13, 322-327. doi:10.1016/j.ecolind.2011.06.031

Muhammad N, Dai ZM, Xiao KC, Meng J, Brookes PC. 2014. Changes in microbial community structure due to biochar generated from different feed stocks and their relationships with soil chemical properties. Geoderma, 226, 270-278. doi.org/10.1016/j.geoderma. 2014.01.023

Nayak AK, Gangwar B, Shukla AK, Mazumdar SP et al. 2012. Long-term effect of different integrated nutrient management on soil organic carbon and its fractions and sustainability of rice-wheat system in Indo Gangetic Plains of India. Field Crops Research, 127, 129-139. doi:10.1016/ j.fcr.2011.11.011

Opala PA, Okalebo JR, Othieno CO. 2012. Effects of Organic and Inorganic Materials on Soil Acidity and Phosphorus Availability in a Soil Incubation Study. ISRN Agronomy, 1-10. doi:10.5402/2012/597216

Pandey D, Agrawal M, Bohra JS, Singh J. 2014. Effects of conventional tillage and no tillage permutations on extracellular soil enzyme activities and microbial biomass under rice cultivation. Soil \& Tillage Research, 136, 51-60. doi:10.1016/j.still.2013.09.013

Preethi B, Poorniammal R, Balachandar D, Karthikeyan S. 2013. Long-term organic nutrient managements foster the biological properties and carbon sequestering capability of a wetland rice soil. Archives of Agronomy and Soil Science, 59, 1607-1624. doi:10.1080/03650340.2012.755260

Raja R, Nayak AK, Shukla AK, Rao KS, Gautam P. 2015. Impairment of soil health due to fly ash-fugitive dust deposition from coal-fired thermal power plants. Environmental Monitoring and Assessment, 187, 679. doi:10.1007/s10661-015-4902-y

Ramirez-Villanueva DA, Bello-López JM, Navarro-Noya YE et al. 2015. Bacterial community structure in maize residue amended soil with contrasting management practices. Applied Soil Ecology, 90, 49-59. doi:10.1016/j.apsoil.2015.01.010

Ross DJ. 1990. Estimation of Soil Microbial C by a Fumigation Extraction Method - Influence of Seasons, Soils and Calibration with the Fumigation Incubation Procedure. Soil Biology and Biochemistry, 22, 295-300. doi: 10.1016/0038-0717(90)90103-7

Shahid M, Nayak AK, Puree C, Tripathi R et al. 2017. Carbon and nitrogen fractions and stocks under 41 years of chemical and organic fertilization in a subhumid tropical rice soil. Soil \& Tillage Research, 170, 136-146. doi:10.1016/j.still.2017.03.008

Page $13 / 18$ 
Shi JY, Yuan XF, Lin HR, Yang YQ, Li ZY. 2011. Differences in soil properties and bacterial communities between the rhizosphere and bulk soil and among different production areas of the medicinal plant Fritillaria thunbergii. International journal of molecular sciences, 12, 3770-3785. doi:10.3390/ijms12063770

Six J, Frey SD, Thiet RK, Batten KM. 2006. Bacterial and Fungal Contributions to Carbon Sequestration in Agro-ecosystems. Soil Science Society of America Journal, 70, 555-569. doi:10.2136/sssaj 2004.0347

Snyder JD, Trofymow JA. 1984. A rapid accurate wet oxidation diffusion procedure for determining organic and inorganic carbon in plant and soil samples. Communications in Soil Science and Plant Analysis, 15, 587-597. doi:10.1080/00103628409367499

Su JQ, Ding LJ, Xue K, Yao HY, Quensen J et al. 2015. Long-term balanced fertilization increases the soil microbial functional diversity in a phosphorus-limited paddy soil. Molecular Ecology, 24, 136-150. doi:10.1111/mec.13010

Tan H, Barret M, Mooij MJ, Rice O, Morrissey JP, Dobson A, Griffiths B, O'Gara F. 2013. Long-term phosphorus fertilisation increased the diversity of the total bacterial community and the phoD phosphorus mineraliser group in pasture soils. Biology and Fertility of Soils, 49, 661-672. doi:10.1007/s00374-012-0755-5

Tang Y, Zhang X, Li D, Wang H, Chen F, Fu X, Fang X, Sun X, Yu G. 2016. Impacts of nitrogen and phosphorus additions on the abundance and community structure of ammonia oxidizers and denitrifying bacteria in Chinese fir plantations. Soil Biology and Biochemistry, 103, 284-

293. doi:10.1016/j.soilbio.2016.09.001

Tautges NE, Sullivan TS, Reardon CL, Burke IC. 2016. Soil microbial diversity and activity linked to crop yield and quality in a dryland organic wheat production system. Applied Soil Ecology, 108, 258-268. doi:10.1016/j.apsoil.2016.09.003

Tejada M, Gonzalez JL, García-Martínez AM, Parrado J. 2008. Application of a green manure and green manure composted with beet vinasse on soil restoration: Effects on soil properties. Bioresource Technology, 99, 4949-4957. doi:10.1016/j.biortech.2007.09.026

Tian S, Ning T, Wang Y, Liu Z, Li G, Li Z, Lal R. 2016. Crop yield and soil carbon responses to tillage method changes in North China. Soil \& Tillage Research, 163, 207-213. doi:10.1016/j.still.2016.06.005

Turner TR, Ramakrishnan K, Walshaw J, Heavens D, Alston M et al. 2013. Comparative metatranscriptomics reveals kingdom level changes in the rhizosphere microbiome of plants. The ISME Journal, 7, 2248-2258. doi:10.1038/ismej.2013.119

Wanjiru L, Acosta-martínez V, Debryun J, Schaeffer S, Tyler D et al. 2015. Long term tillage, cover crop, and fertilization effects on microbial community structure, activity: Implications for soil quality. Soil Biology and Biochemistry, 89, 24-34. doi:10.1016/ j.soilbio.2015.06.016

Weber KP, Gehder M, Legge RL. 2008. Assessment of changes in the microbial community of constructed wetland mesocosms in response to acid mine drainage exposure. Water Research, 42, 180-188. doi:10.1016/j.watres.2007.06.055

Wezel A, Casagrande M, Celette F, Vian JF, Ferrer A, Peigné J. 2014. Agroecological practices for sustainable agriculture: A review. Agronomy for Sustainable Development, 34, 1-20. doi:10.1007/s13593-013-0180-7

Witt C, Gaunt JL, Galicia CC, Ottow JCG, Neue HU. 2000. A rapid chloroform-fumigation extraction method for measuring soil microbial biomass carbon and nitrogen in flooded rice soils. Biology and Fertility of Soils, 30, 510-519. doi:10.1007/s003740050030

Xu W, Ge Z, Poudel DR. 2015. Application and optimization of biolog ecoplates in functional diversity studies of soil microbial communities. In MATEC Web of Conferences. 22, pp 04015.

Xu Z, Yu G, Zhang X, Ge J, He N, Wang Q, Wang D. 2015. The variations in soil microbial communities, enzyme activities and their relationships with soil organic matter decomposition along the northern slope of Changbai Mountain. Applied Soil Ecology, 86, 19-29. doi.org/10.1016/j.apsoil.2014.09.015

Ya-Juan LI, Xing CH, Shamsi IH, Ping FA, Xian-Yong LI. 2012. Effects of irrigation patterns and nitrogen fertilization on rice yield and microbial community structure in paddy soil. Pedosphere. 22, 661-672. doi:10.1016/S1002-0160(12)60051-4

Yu C, Hu XMM, Deng W, Li Y, Xiong C, Ye CHH, Han GMM, Li X. 2015. Changes in soil microbial community structure and functional diversity in the rhizosphere surrounding mulberry subjected to long-term fertilization. Applied Soil Ecology, 86, 30-40. doi:10.1016/j.apsoil.2014.09.013

Zhang QC, Shamsi IH, Xu DT, Wang GH, Lin XY, Jilani G et al. 2012. Chemical fertilizer and organic manure inputs in soil exhibit a vice versa pattern of microbial community structure. Applied Soil Ecology, 57, 1-8. doi:10.1016/j.apsoil.2012.02.012

Zhang X, Zhong Y, Yang S, Zhang W, Xu M, Ma A, Zhuang G, Chen G, Liu W. 2014. Diversity and dynamics of the microbial community on decomposing wheat straw during mushroom compost production. Bioresource Technology, 170, 183-195. doi:10.1016/ j.biortech.2014.07.093

Zhong WH, Cai ZC. 2007. Long-term effects of inorganic fertilizers on microbial biomass and community functional diversity in a paddy soil derived from quaternary red clay. Applied Soil Ecology, 36, 84-91. doi:10.1016/j.apsoil.2006.12.001

Zhou J, Guo W, Wang R, Han X, Q Wang. 2008. Microbial community diversity in the profle of an agricultural soil in northern China. Applied Soil Ecology, 20, 981-988. doi.org/10.1016/S1001-0742(08)62197-X 
Zhu L, Hu N, Yang M, Zhan X, Zhang Z. 2014. Effects of different tillage and straw return on soil organic carbon in a rice-wheat rotation system. PLoS One, 9, e88900. doi:10.1371/journal.pone.0088900

\section{Figures}

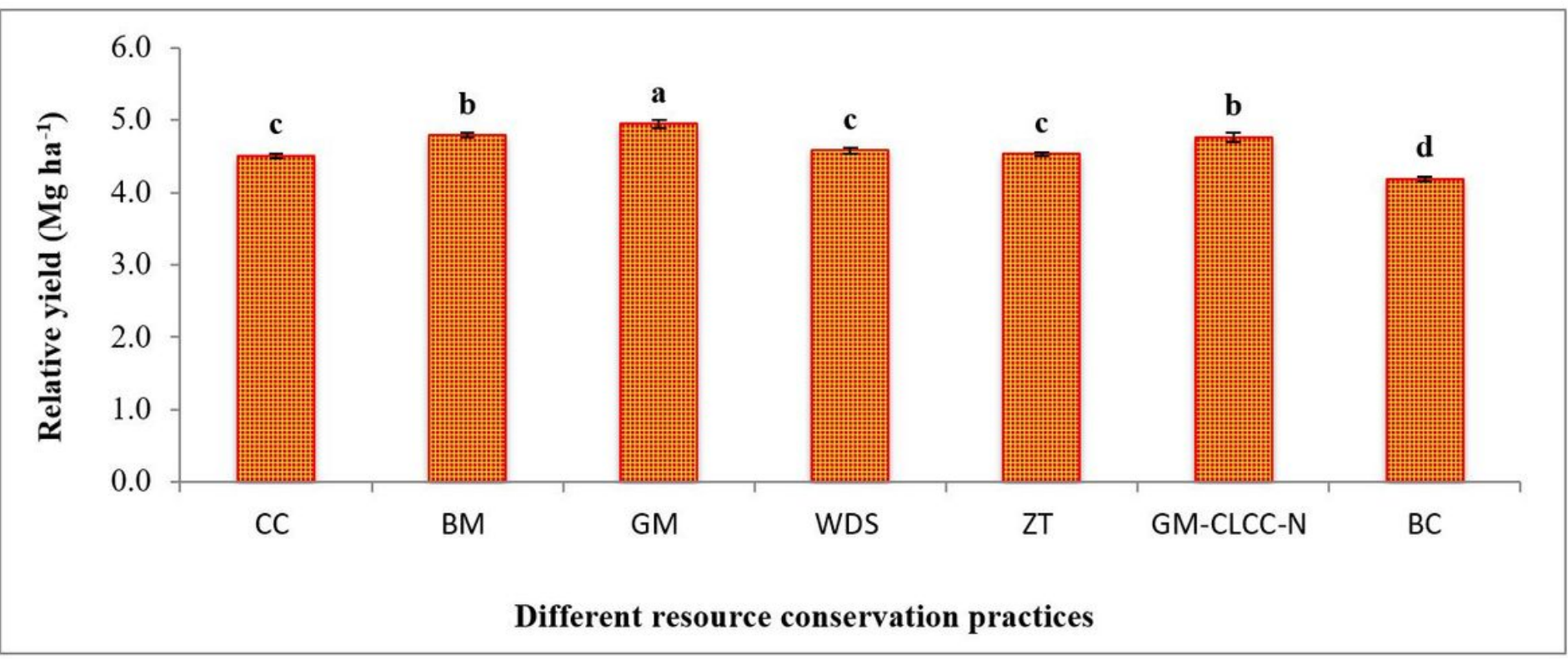

Figure 1

Relative yield (Mg ha-1) under different resource conservation practices [Here, CC: conventional control; BM: brown manuring; GM: green manuring; WDS: wet drum seeding; ZT: zero tillage; GM-CLCC-N: green manuring- CLCC-N; BC: biochar]

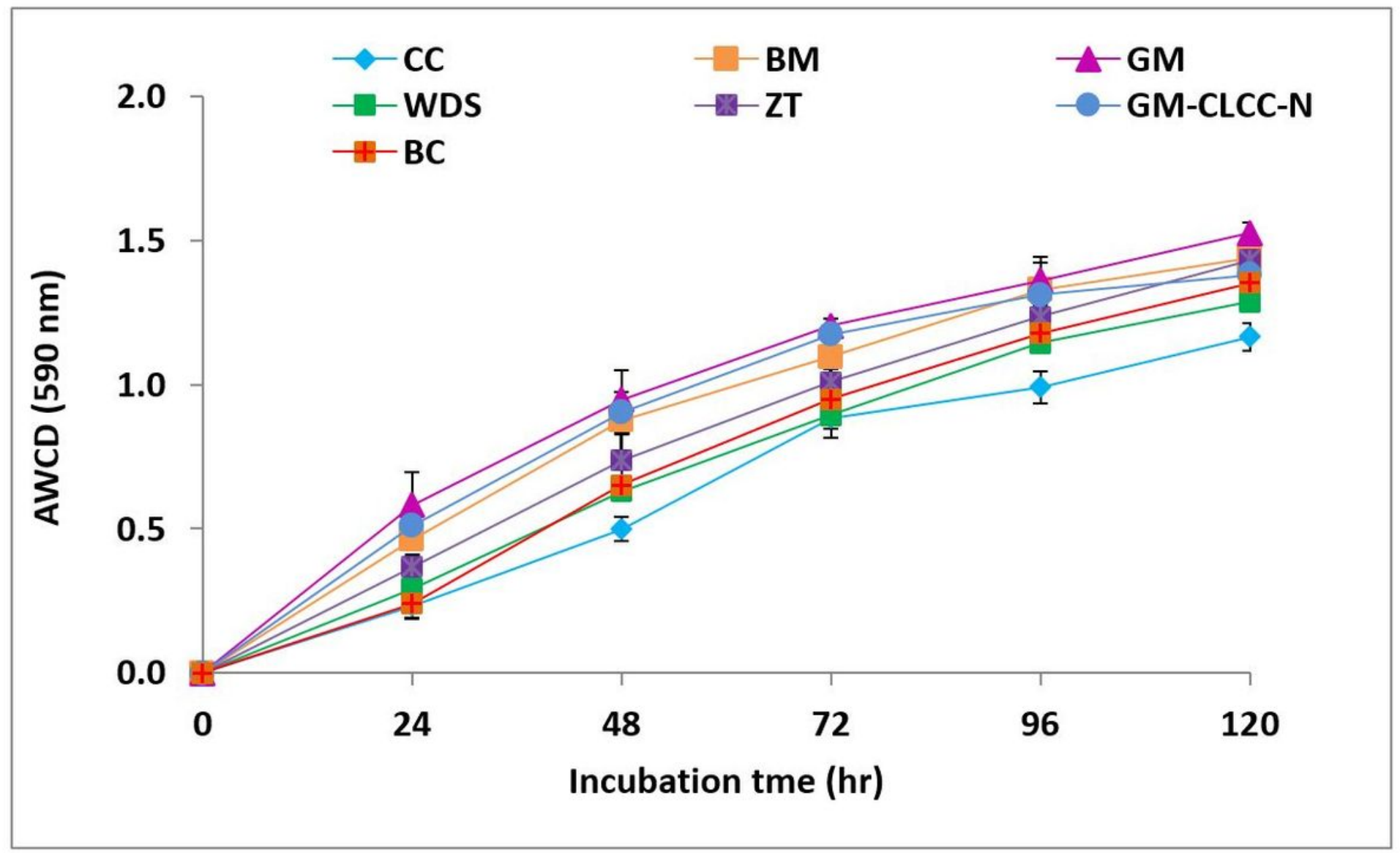

Figure 2 

bars, $n=3$. [Here, CC: conventional control; BM: brown manuring; GM: green manuring; WDS: wet drum seeding; ZT: zero tillage; GM-CLCC-N: green manuringCLCC-N; BC: biochar]

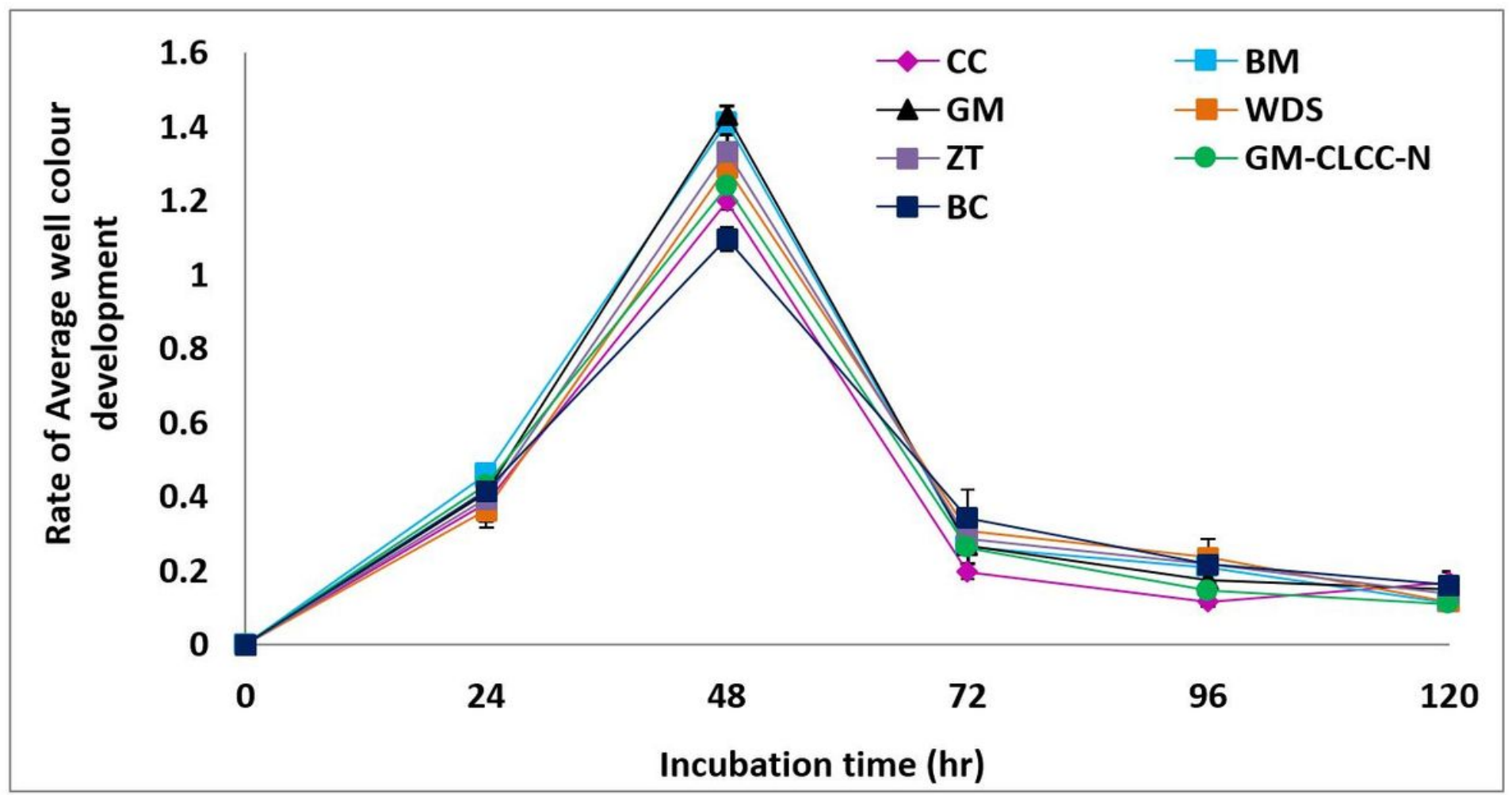

Figure 3

Variation of average well colour development (AWCD) for five consecutive days of the soil under resource conservation. Mean value with standard deviation bars, $n=3$. [Here, CC: conventional control; BM: brown manuring; GM: green manuring; WDS: wet drum seeding; ZT: zero tillage; GM-CLCC-N: green manuringCLCC-N; BC: biochar] 


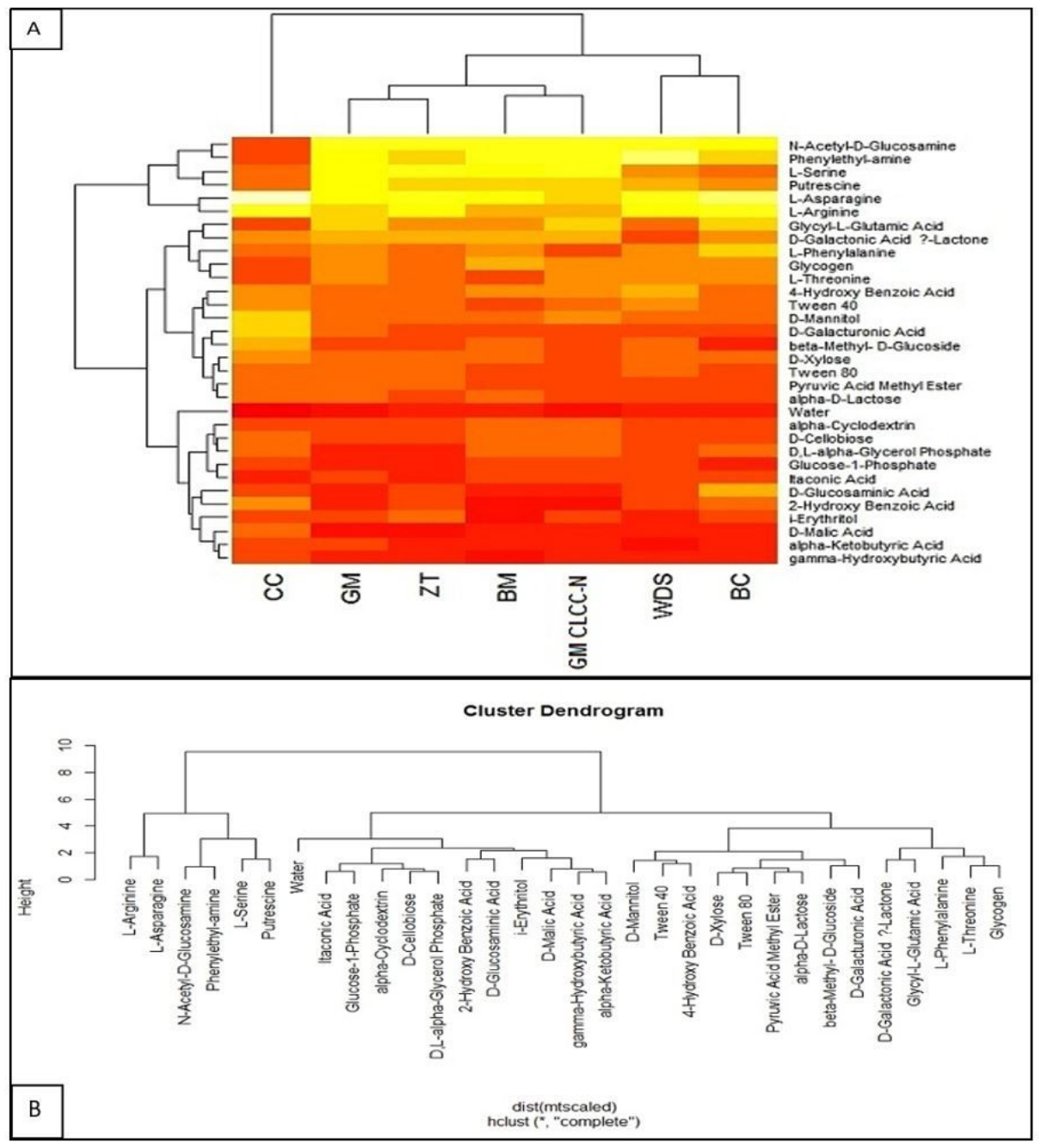

\section{Figure 4}

Heat map (A) of microbial consumption of six major groups of carbon sources of soil under different resource conservation with cluster dendrogram (B). [Here, CC: conventional control; BM: brown manuring; GM: green manuring; WDS: wet drum seeding; ZT: zero tillage; GM-CLCC-N: green manuring- CLCC-N; BC: biochar and AA: Amino acids; AM: Amines; CB: Carbohydrates; CA: Carboxylic acids; PO: Polymers; PC: Phenolics compounds.] 

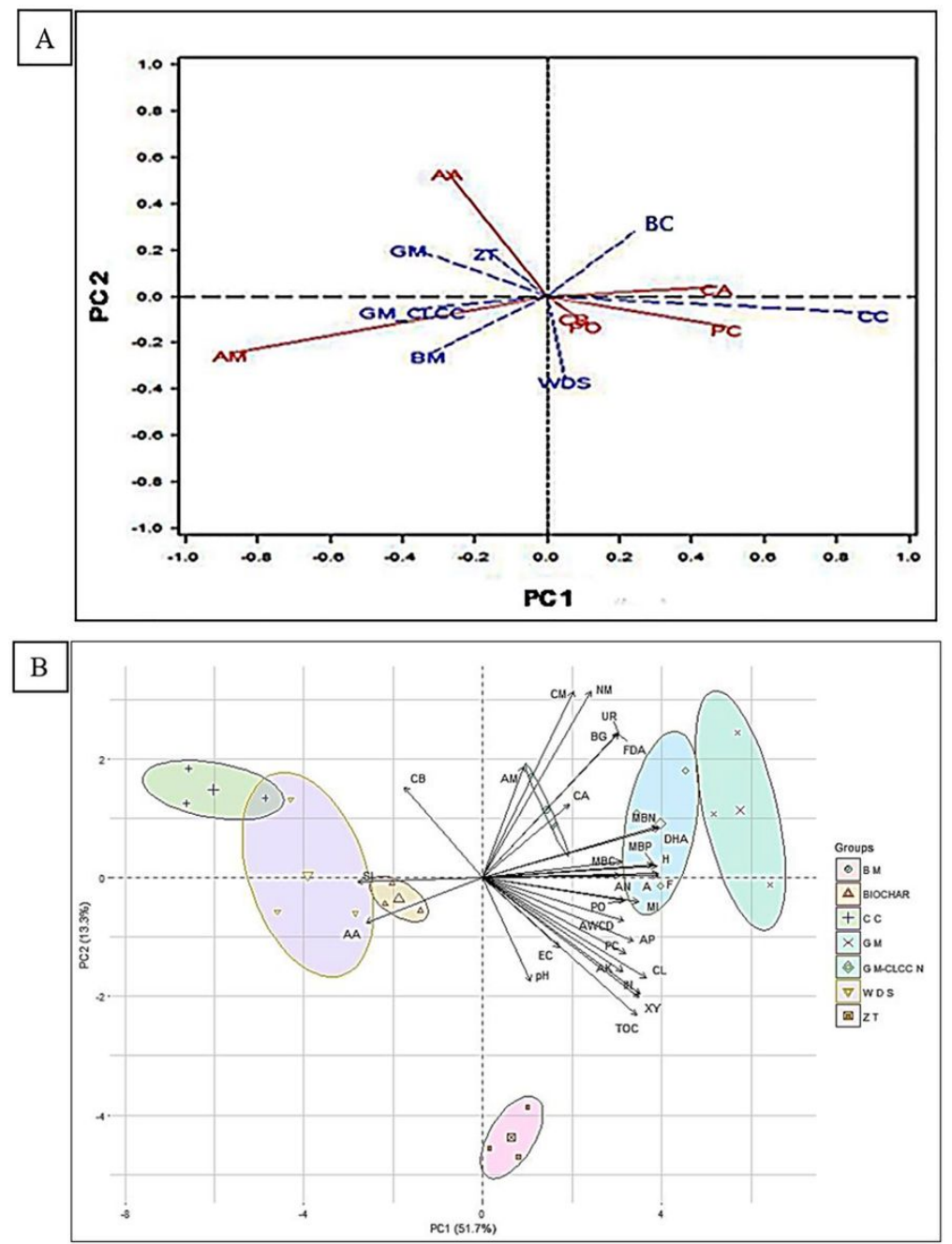

\section{Figure 5}

(A) Biplot analysis based on $72 \mathrm{~h}$ biolog data indicating separation of seven treatments and (B) Biplot of principal components depicting relationship within 7 treatment and 17 parameters of resource conservation experiment. [AA: Amino acids; AM: Amines; CB: Carbohydrates; CA: Carboxylic acids; PO: Polymers; PC: Phenolics compounds). Values in parentheses indicate percentage contribution by PC1 and PC2. [Here, CC: conventional control; BM: brown manuring; GM: green manuring; WDS: wet drum seeding; ZT: zero tillage; GM-CLCC-N: green manuring- CLCC-N; BC: biochar] 